
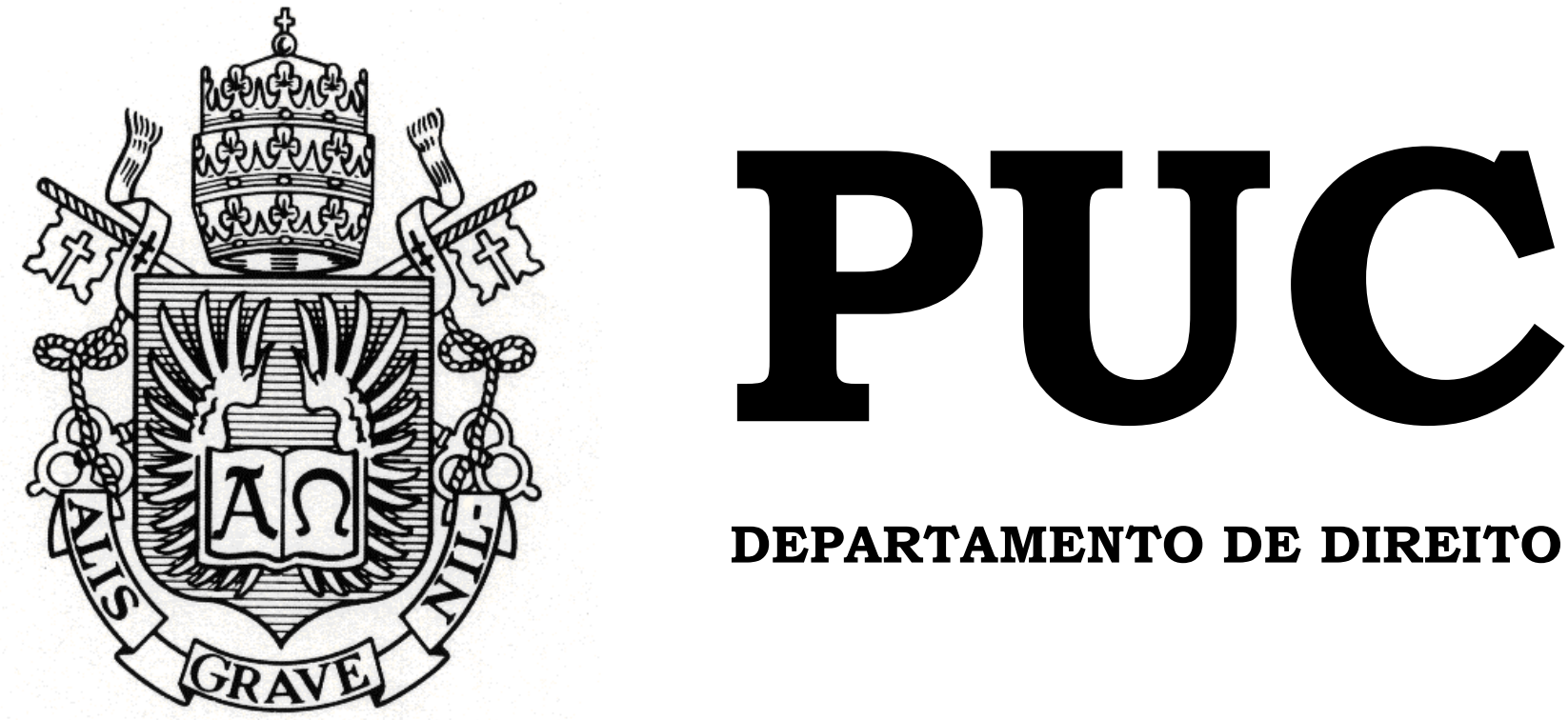

DEPARTAMENTO DE DIREITO

\title{
A PUBLICIDADE OPRESSIVA NAS DECISÕES DO PROCESSO CRIMINAL E SEUS REFLEXOS NO PRINCÍPIO DA PRESUNÇÃO DE INOCÊNCIA
} Por

Beatriz Bassil López

ORIENTADOR (A): Breno Melaragno Costa 2018.1

PONTIFÍCIA UNIVERSIDADE CATÓLICA DO RIO DE JANEIRO RUA MARQUÊS DE SÃO VICENTE, 225 - CEP 22453-900 RIO DE JANEIRO - BRASIL 


\title{
A PUBLICIDADE OPRESSIVA NAS DECISÕES DO PROCESSO CRIMINAL E SEUS REFLEXOS NO PRINCÍPIO DA PRESUNÇÃO DE INOCÊNCIA
}

\author{
por
}

\section{Beatriz Bassil López}

\begin{abstract}
Monografia apresentada ao Departamento de Direito da Pontificia Universidade Católica do Rio de Janeiro (PUC-Rio) para a obtenção do Título de Bacharel em Direito.
\end{abstract}


"Aquilo que foi criado para ser instrumento da democracia direta não deve ser convertida em mecanismo de opressão simbólica." Pierre Bourdieu 


\section{AGRADECIMENTOS}

A efemeridade da vida faz com que nos lembremos sempre de agradecer aqueles que fazem dessa jornada mais especial. E que bom que é assim. Contudo, nem sempre isso é uma tarefa fácil, inclusive, dentro desse trabalho de conclusão, julgo ter sido a mais difícil. Penso assim, porque nem com todas as palavras do dicionário eu conseguiria formar as expressões certas para demonstrar todo o amor e gratidão em ter cada uma dessas pessoas na minha vida. Todos os que passaram e, principalmente, aqueles que permaneceram foram fundamentais para meu crescimento pessoal, profissional e por me tornar, a cada dia, um ser humano melhor. Sendo assim, ficam aqui, meus agradecimentos:

Agradeço, primeiramente, a mais bonita estrela e querida avó Liete, por ter sido, em vida, minha grande incentivadora educacional. Sei o quanto este momento significaria para ela e quanta felicidade restaria em seu olhar.

A minha mãe, Sumaia Bassil, por ter me dado apoio incondicional e por ser minha inspiração diária me fazendo lembrar que nunca é tarde para irmos atrás de nossos sonhos e sermos felizes.

Ao meu pai, Juan López, por me fazer acreditar que super-heróis existem, sempre se esforçando para me dar o melhor e por me fazer enxergar que o trabalho é o único meio capaz de garantirmos o que desejamos.

Ao meu irmão, Pedro, por sempre me mostrar que a calma é um ótimo exercício a ser trabalhado e por me estender a mão sempre quando foi preciso. 
A minha avó, Lucinda, e minha tia, Herminia, por sempre me acalmarem quando foi necessário e por serem minhas eternas psicólogas de vida.

Ao Bruno Gomes, por todo o suporte durante momentos importantes da faculdade.

As minhas queridas melhores amigas de vida, Natasha, Carol, Aninha, Iasmim e Marina, por sempre serem aquele ombro amigo, seja para chorar, seja para sorrir.

As minhas amigas da Procuradoria Geral do Estado, Fernanda, Marina e Gabi, por todas as conversas, apoio e carinho durante os últimos meses importantes da faculdade.

Aos meus queridos amigos da Defensoria Pública, em especial ao II Tribunal do Júri, por terem sido minha segunda família e por terem me ensinado tanto de direito penal e, principalmente, de humanidade.

A todos vocês, obrigada por serem parte da minha vida. Este ciclo se encerra, mas muitos outros virão e que assim seja, mas ao lado de vocês. 
López, Beatriz Bassil. A Publicidade Opressiva Nas Decisões Do Processo Criminal E Seus Reflexos No Princípio Da Presunção De Inocência. Rio de Janeiro, 2018. 97 páginas. Trabalho de Conclusão de Curso - Departamento de Direito. Pontifícia Universidade Católica do Rio de Janeiro.

\section{RESUMO}

Este trabalho tem como objetivo abordar o papel da mídia dentro da sociedade brasileira, sua influência nas decisões do processo penal e seus reflexos, principalmente, no princípio da presunção de inocência, analisando como o Poder Judiciário se relaciona com os meios de comunicação de massa dentro do Estado Democrático de Direito.

Será feita uma breve análise da evolução histórica da formação da mídia que temos hoje, desde o nascimento da indústria cultural até a expansão desta pela globalização, passando por conceitos importantes que nos fazem entender como a mídia desempenha seu papel dentro da sociedade.

Em seguida, será abordado o direito constitucional da liberdade de expressão e informação, assim como o direito a um julgamento criminal justo e todos os subprincípios que este envolve, visando demonstrar a relevância de ambos os direitos para o Ordenamento Jurídico brasileiro.

Neste percorrer, será demonstrada a efetiva colisão entre os direitos apresentado buscando-se, ao final, estabelecer através de critérios de ponderação, soluções possíveis que garantam o direito do réu em ser submetido a um julgamento criminal justo sem impedir a realização do direito à liberdade de expressão e informação. 
PALAVRAS-CHAVES: Indústria cultural - sociedade do espetáculo - mídia - poder judiciário - processo penal - liberdade de expressão e informação julgamento criminal justo - princípio da presunção de inocência - colisão de direitos fundamentais - ponderação de princípios 


\section{Sumário}

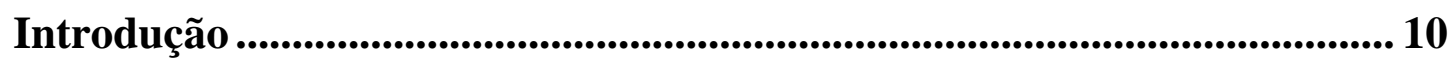

Capítulo 1: O Papel Da Mídia Na Construção Do Imaginário Coletivo Em

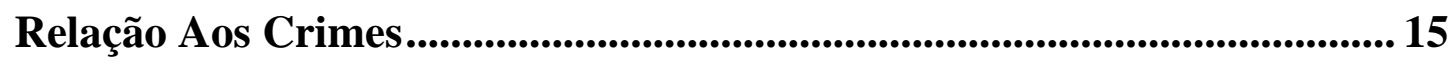

Capítulo 2. O Princípio Da Liberdade De Expressão E De Informação Na Constituição Federal De 1988............................................................................... 25

2.1 As Teorias Sobre A Liberdade De Expressão Na Constituição Norte Americana E O Alcance Da Primeira Emenda ............................................... 25

2.2. A Liberdade De Expressão Na Constituição Federal De 1988 .................. 28

2.3 Da Liberdade de Informação na Constituição Federal de 1988 .................. 31

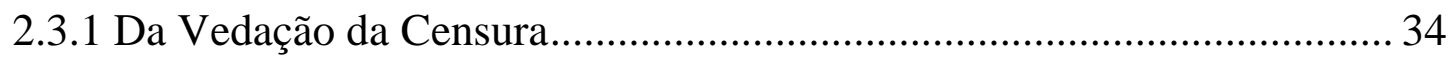

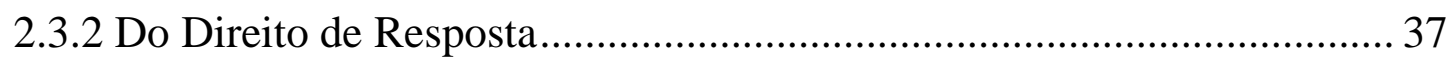

2.4 A Jurisprudência Nos Tribunais Acerca Do Princípio Da Liberdade De Expressão E Informação Em Colisão Com Outros Direitos Fundamentais..... 40

Capítulo 3. O Direito A Um Julgamento Criminal Justo E Os Reflexos No Princípio Da Presunção De Inocência................................................................... 48

3.1 O Princípio Do Devido Processo Legal - Julgamento Criminal Justo - Na

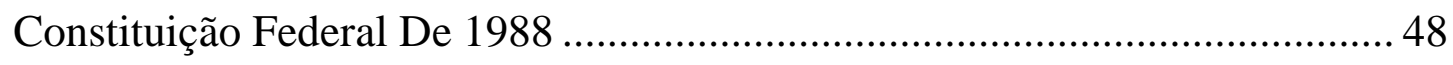

$3.2 \mathrm{O}$ princípio da presunção de inocência....................................................... 50

3.2.1 O Caso Do Goleiro Bruno E Eliza Samúdio ............................................. 54

3.2.2. A Operação Lava-Jato e o Vazamento Dos Áudios Entre Luís Inácio Lula Da Silva e a ex-Presidente Dilma Rousseff ............................................ 58

3.2.3. A Influência Opressiva Midiática E A Condenação Automática Do Réu

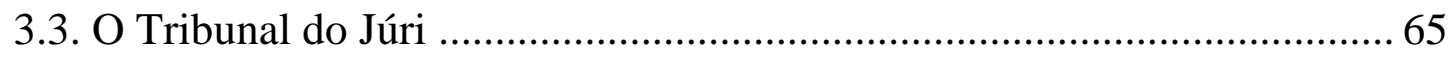




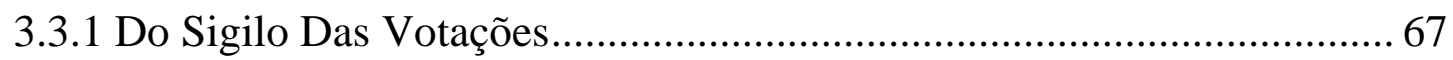

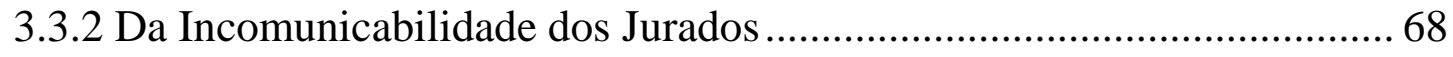

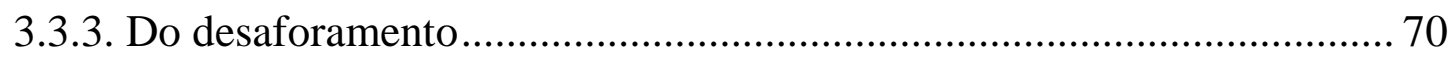

3.4 A publicidade das decisões na Constituição de 1988................................. 74

Capítulo 4. Colisão De Direitos Fundamentais: Presunção De Inocência E Julgamento Criminal Justo Versus Liberdade De Expressão E De Imprensa ................................................................................................................................. 77

4.1 A Diferenciação Entre Regras E Princípios E A Aplicação Das Técnicas

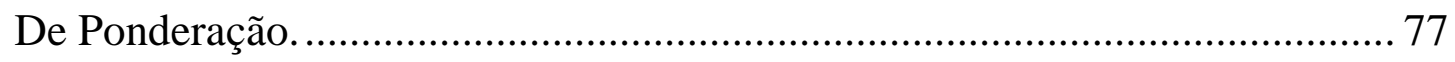

4.2 Identificação Do Conflito Entre Liberdade De Expressão/Informação E Direito A Um Julgamento Criminal Justo ........................................................ 81

4.3 Fixação De Critérios De Ponderação Para A Resolução Do Conflito Apresentado E Possíveis Soluções Compatíveis Com A Constituição Federal

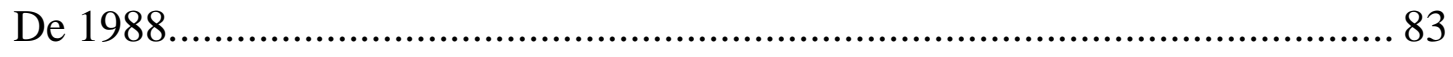

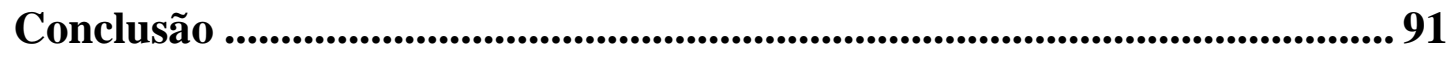

Bibliografia................................................................................................................... 94 


\section{Introdução}

Este trabalho tem como objetivo principal analisar a influência da mídia nas decisões do processo penal e os reflexos causados, por essa, no princípio constitucional da presunção de inocência.

Para a realização deste propósito será examinado a colisão entre dois direitos fundamentais que possuem ampla relevância para a efetivação do Estado Democrático de Direito - a liberdade de expressão e informação e o julgamento criminal justo.

O presente estudo, também, terá como referência e inspiração principal o livro da Desembargadora Simone Schreiber, "A publicidade opressiva de julgamentos criminais", que expõe com brilhantismo a temática apresentada.

A pesquisa será dividida em quatro capítulos, cujos temas a serem abordados em cada capítulo, também, são selecionados a partir da questão central - a demonstração da influência midiática nas decisões no processo penal.

O primeiro capítulo abordará alguns conceitos que não correspondem a área do direito, mas que são essenciais para entendermos como os meios de comunicação têm influência no pensamento da sociedade de consumo, no processo de criminalização e no sistema penal.

A indústria cultural e a globalização, responsável pela expansão desta, são fatores determinantes para compreendermos a sociedade midiatizada, na qual nos encontramos hoje. 
A mídia torna-se, dentro de uma sociedade marcada pelo consumo, a principal responsável por informar a população e estabelecer, assim, padrões comportamentais. Transforma-se, portanto, em verdadeiro instrumento de controle social decidindo o que será informado e como essa informação deverá ser compreendida.

É incontestável a importância da mídia na efetivação da Democracia plena, porém os abusos causados pelas empresas de comunicação ao informar, principalmente, quando o assunto diz respeito a justiça criminal fazem com que a mídia acabe se distanciando da sua função precípua, informar a população dos acontecimentos de interesse coletivo - mantendo-se equidistante dos fatos - para opinar, incutindo verdadeiros juízos de valor e aumentando exageradamente na população os sentimentos de insegurança, medo, impunidade, etc.

A sociedade do espetáculo e as notícias sensacionalistas propagadas pela mídia não negam o objetivo da indústria cultural - obtenção de lucro através da notícia como arte - percebe-se, assim, diante dessa indústria do espetáculo que a opinião pública é, na verdade, uma opinião publicada e o resultado disso tem especial relevo quando afeta o papel do poder judiciário na solução dos conflitos, principalmente, os criminais.

O segundo capítulo, por sua vez, trará ao presente estudo dois princípios fundamentais dispostos na Constituição Federal de 1988, o princípio da liberdade de expressão e o da liberdade de informação. 
Para isso, serão analisadas algumas teorias, observando-se, a partir dessas, em que situações tais princípios poderão sofrer limitações quando estiverem em presente conflito com outros direitos fundamentais.

Após vinte e um anos de regime ditatorial no Brasil, a liberdade de expressão e de informação presentes no texto constitucional de 1988 tornaramse um dos direitos pressupostos da Democracia e da modernidade, não somente por desempenharem papel fundamental para a estruturação do regime democrático, mas por serem responsáveis pela manutenção deste.

O Estado Democrático de Direito ao transferir o poder do povo para seus representantes eleitos instaura a necessidade de uma fiscalização externa e de um fluxo de informações capaz de controlar a atuação desses representantes.

A mídia, portanto, no desempenho da função de informar e de exercer, por assim dizer, com excelência os direitos fundamentais da liberdade de expressão e de informação acaba por representar o papel de watchdog (cão de guarda) das instituições democráticas, limitando, verdadeiramente, o exercício do poder na democracia.

Posto isso, para que melhor se compreenda os dois direitos abordados, no capítulo dois, o estudo será dividido. Primeiro se abordará o direito à liberdade de expressão e após se tratará do direito à liberdade de informação. 
O terceiro capítulo, abordará os direitos fundamentais e individuais dos cidadãos que, de certa forma, limitam a atuação do Estado na persecução penal dentro da Democracia Constitucional na qual vivemos. Também trará o estudo de dois casos, que demonstram como a mídia é capaz de influenciar os julgamentos criminais.

Assim, como o direito à liberdade de expressão e informação são fundamentais para o exercício efetivo da Democracia, as garantias que serão abordadas neste capítulo também são.

Todos esses direitos que regem a investigação de fatos criminosos e de seus responsáveis têm como função primeira a limitação da atividade persecutória praticada pelo Estado, de modo a assegurar que esta prática seja realizada racionalmente e não arbitrariamente como eram realizadas nos tempos de ditadura militar.

Portanto, a imposição da pena dentro da Democracia Constitucional somente é legitima se inserida dentro das garantias constitucionais que compõe o processo penal.

Dessa forma, neste capítulo, serão apresentadas tais garantias e, além disso, buscar-se-á demonstrar a importância que elas têm dentro da sociedade, principalmente, no momento no qual vivemos - de clamor por segurança pública e de relativização dessas garantias pelo imaginário coletivo de que são elas que comprometem a eficiência do sistema penal punitivo. 
O quarto e último capítulo tem como objetivo buscar soluções harmônicas com a própria Constituição visando a compatibilização dos direitos tratados nos capítulos anteriores quando estes entram em colisão.

Veremos que a liberdade de expressão, a liberdade de informação e de imprensa é fator essencial para o controle da atuação dos órgãos públicos, principalmente, do Judiciário que não se elege por meio do voto popular.

Ocorre que, como, também, poderemos observar, o direito a um julgamento criminal justo é, igualmente, uma garantia constitucional, o que faz com que, em alguns momentos, a veiculação excessiva e a forma de noticiar os fatos, principalmente criminais, acabe violando direitos que da mesma forma têm proteção constitucional.

Sendo assim, ambos os direitos abordados neste trabalho possuem valor essencial para o Estado Democrático de Direito e, conjuntamente, com outros direitos, o legitimam. De forma que, se é latente a importância da mídia na veiculação de informações de interesse coletivo e que, portanto, não se poderia proibir a priori a divulgação de qualquer tipo de notícia que tivesse esse fim, também, parece evidente que não se pode permitir que cidadãos sejam julgados sem que se observe as garantias constitucionais e individuais que correspondem a um julgamento criminal justo.

Para isso, serão estabelecidos critérios de ponderação com base nos estudos traçados por Humberto Ávila e Ana Paula de Barcellos e, ao final, serão sugeridas possíveis soluções para a colisão entre esses dois direitos constitucionais que possuem ampla importância para a efetivação da Democracia Constitucional na qual vivemos. 


\section{Capítulo 1: O Papel Da Mídia Na Construção Do Imaginário Coletivo Em Relação aos crimes}

Para entendermos a atual influência da mídia no processo de criminalização é necessário percorrer alguns precedentes históricos. A indústria cultural, o mundo globalizado e a sociedade do espetáculo são, por assim dizer, conceitos chaves para compreendermos as razões pelas quais a mídia ao tornar-se o meio de acesso à realidade das pessoas, consegue retirar a capacidade crítica dessas.

Na primeira metade do século XX, o movimento liberal começou a delinear o modelo capitalista de produção e concentração de riquezas. Ocorre que, foi neste mesmo século que, filósofos, sociólogos e cientistas sociais, pretendendo analisar criticamente as ideias Marxistas sobre as relações de produção econômica e de dominação entre as classes sociais criaram a Escola de Frankfurt, movimento responsável por traçar os conceitos de "indústria cultural" e "cultura de massa".

Além de elaborarem tais conceitos, esses estudiosos tinham como objetivo estabelecer uma reflexão crítica acerca da dominação do indivíduo pela massificação dos bens culturais. Com isso, percebemos que a relação entre a mídia e a sociedade de consumo começou a ser esboçada não neste século, mas no anterior. 
A expressão indústria cultural, criada por Adorno e Horkheimer, é utilizada, essencialmente, para designar o modo de fazer cultura dentro da lógica da produção industrial. Nesta, a arte é produzida com o objetivo de alcançar lucros. Sendo assim, compreender essa dinâmica é, igualmente, identificar como a mass media (conjunto de comunicação de massa), dentro de uma sociedade marcada pelo consumo de massa, transforma o crime em uma mercadoria.

Em uma época definida pela expansão de técnicas, a arte torna-se matéria-prima para a industrialização da cultura, que se transforma em um produto certo para um consumo rápido e irrefletido.

Não somente, o homem que antes era mão de obra dentro da sociedade passa a ser, dentro de uma sociedade marcada pela indústria cultural, consumidor, tornando-se, assim, essencial para a dinâmica de manipulação do consumo.

Certo é que, todos esses fatores foram essenciais para o crescimento da indústria cultural, principalmente, à similaridade dos produtos oferecidos, uma vez que não era mais necessária uma reflexão sobre o que se estava consumindo, apenas consumia-se.

Com isso, esta indústria ao determinar o próprio consumo e retirar a capacidade de avaliação crítica do seu público consumidor começou a alcançar espaço tanto na sociedade, quanto no contexto socioeconômico. 
Nesse desenvolvimento, a globalização trouxe novos rumos à indústria cultural. A evolução tecnológica, informacional e os novos recursos tecnológicos aceleraram o processo de massificação dos produtos e o consumidor que antes era sujeito passivo na dinâmica comunicacional, tornouse participante ativo.

Dessa forma, pode-se dizer que, a globalização ao aumentar o domínio sobre o conhecimento de mundo de seus consumidores foi determinante para fazer com que a indústria cultural tivesse controle sobre a massa.

Fato é que, ainda que adaptada ao mundo globalizado, a indústria cultural continua fazendo parte do nosso dia a dia. A expressão, portanto, ainda que ajustada aos novos rumos se mantém atual e indispensável para entendermos a dinâmica da influência da mídia no sistema penal e no processo de criminalização.

Além da expressão "indústria cultural”, trazida pela Escola de Frankfurt, o conceito de sociedade do espetáculo é imprescindível para que se compreenda de forma mais aprofundada a influência que a mídia desempenha na construção do imaginário coletivo sobre os atos criminosos. 
O espetáculo conduz as pessoas a darem tamanha relevância ao consumo que os assuntos significativos de suas vidas acabam por ficar em segundo plano. A mídia, nesse sentido, desempenha papel primordial dentro dessa sociedade, uma vez que é através dela que o público tem acesso as imagens. A imagem, portanto, é o mecanismo mais eficaz de representação da realidade, tornando-se um novo produto dentro dessa sociedade de consumo que, entorpecida pelo espetáculo, não questiona, apenas consome o que lhe é oferecido. $^{1}$

Assim, também, afirma Rubens Casara, em seu artigo “A espetacularização do processo penal":

Sabe-se que o espetáculo é uma construção social, uma relação intersubjetiva mediada por sensações, em especial produzidas por imagens e, por vezes, vinculadas a um enredo. $\mathrm{O}$ espetáculo tornou-se também um regulador das expectativas sociais, na medida em que as imagens produzidas e o enredo desenvolvido passam a condicionar as relações humanas: as pessoas, que são os consumidores do espetáculo, exercem a dupla função de atuar e assistir, influenciam no desenvolvimento e são influenciadas pelo espetáculo.2

A informação, por sua vez, e todo o seu conteúdo político, econômico e cultural cedem espaço ao espetacular. $\mathrm{O}$ ato de informar passa a agregar o fator diversão, tornando legítimo uma imprensa que pouco se importa com a informação verdadeira, apenas the sendo estimado o escândalo. No que diz respeito ao conflito penal, o discurso punitivista prevalece transformando-se em espetáculo. Banalizam-se os fatos relevantes e criam-se caricaturas midiáticas. É nesse contexto que:

1 KEHDI, André. Editorial: Mídia, imagem e poder na democracia. Disponível em < https://www.ibccrim.org.br/boletim_artigo/4062-EDITORIAL-Midia-imagem-e-poder-nademocracia $>$. Acesso em 18 de abril de 2018.

2 CASARA, Rubens. A espetacularização do processo penal. Disponível em < http://www.mpsp.mp.br/portal/page/portal/documentacao_e_divulgacao/doc_biblioteca/bibli_servi cos_produtos/bibli_boletim/bibli_bol_2006/122.12.PDF >. Acesso em 18 de abril de 2018. 
Inimigos são eleitos e vítimas purificadas, instigando na sociedade, emoções que vão do medo a insegurança, até sentimentos como o ódio e a vingança que aumentam as expectativas sociais de repressão. Tudo como o enredo de um filme de ação policial, bem ao estilo do show cinematográfico hollywoodiano. ${ }^{3}$

A criminalidade, portanto, se torna um produto interessante aos olhos da mídia, uma vez que além de barato já possui consumidor definido, a massa. A mídia, dessa forma, acaba por ocupar um papel indiscutível na sociedade atual, tendo em vista que ao informar a população, assume o papel de formadora de opinião.

Não há como negar, dessa forma, que a influência da mídia é determinante para a construção do mundo das pessoas. Não apenas determinase o que é informado como, também, estabelece-se comportamentos padrões. A reflexão crítica, nessas circunstâncias, acaba desprezada por essa sociedade.

Há quem diga que no panorama atual a mídia nada mais é do que um quarto poder, em razão do fato de ser ela quem define a agenda setting ${ }^{4}$ e confere significados as palavras, controlando a opinião da massa. Isso, quando se trata de crime, torna-se um "prato cheio" para a manipulação realizada pelos meios de comunicação, uma vez que é esta quem define o que aparecerá e o que desaparecerá da esfera de consciência social. Dessa forma, entende-se que:

3 GOMES, Marcus Alan de Melo. Mídia e sistema penal: as distorções da criminalização nos meios de comunicação. $1^{a}$ ed. - Rio de Janeiro: Revan, 2015. pág. 57

4 Termo usado para definir um tipo de efeito social da mídia que compreende a seleção, disposição e incidência de notícias sobre os temas que o público falará e discutirá. Trata-se dos temas que serão objeto do debate público. FILHO, Ciro. Dicionário de comunicação. Disponível em < https://books.google.com.br/books?id=pf5DAAAQBAJ\&pg=PT32\&dq=agenda+setting+dicionario\&hl=ptBR\&sa $=X \& v e d=0$ ahUKEwjH9dv1kKnbAhWFfpAKHdkxCIsQ6AEIKDAA\#v=onepage\&q=agen da\%20setting\%20dicionario\&f=false $>$ Acesso em 28 de maio de 2018. 
(...) se o crime é selecionado pela agenda midiática, fatalmente estará na agenda pública e muito provavelmente na agenda política. De igual modo, quando a criminalidade integra a agenda política há reflexos na constituição da agenda midiática e automaticamente na agenda pública. Isso quer dizer, em poucas palavras, que ao enfatizar acontecimentos de natureza delituosa, os meios de comunicação chamam a atenção da sociedade e do poder político para o assunto. ${ }^{5}$

Portanto, é possível afirmar que os meios de comunicação têm o poder de construir a realidade social e que, sua capacidade de produzir consenso sobre os temas agendados os converte em expressivo instrumento de controle social - escolhendo o que será apresentado e como a informação deverá ser compreendida.

Sendo assim, a maior visibilidade dada aos atos criminosos dentro de uma sociedade midiatizada importa em um maior controle e, também, no endurecimento da resposta criminal. A mídia que explora o imaginário de seu público, incutindo-o a sensação de insegurança, prende-o pelo emocional. Posto isto, a ideia de que a criminalidade alcança níveis incontroláveis se torna um dos principais fatores na influência do recrudescimento das políticas criminais. Assim, entende-se que:

No processo penal voltado para o espetáculo não há espaço para garantir direitos fundamentais. O espetáculo, como percebeu Debord, 'não deseja chegar a nada que não seja ele mesmo'. A dimensão de garantia, inerente ao processo penal no Estado Democrático de Direito (marcado por limites ao exercício do poder), desaparece para ceder lugar à dimensão de entretenimento. ${ }^{6}$

5 GOMES, Marcus Alan de Melo. Op. cit. pág. 81

6 CASARA, Rubens. A espetacularização do processo penal. Disponível em < http://www.mpsp.mp.br/portal/page/portal/documentacao_e_divulgacao/doc_biblioteca/bibli_servicos _produtos/bibli_boletim/bibli_bol_2006/122.12.PDF >. Acesso em 18 de abril de 2018. 
A linguagem midiática, além de alimentar uma sensação genérica de insegurança, é diretamente responsável pelo processo de criminalização, uma vez que a mídia se utiliza de expressões que acentuam os estereótipos - o que propicia uma natural identificação com a vítima e aumenta um falso rotulamento para identificação dos criminosos.

Esse tipo de linguagem quando difundida e repetida diariamente acaba influenciando o processo de criminalização. Esse processo, inicialmente, é formado por duas etapas, a primária e a secundária.

Entende-se por criminalização primária a elaboração de leis penais, permitindo a sanção de atos e a punição de pessoas que venham a cometê-los. Já a criminalização secundária é a ação punitiva exercida sobre pessoas concretas, cabendo as agências que compõem o sistema penal.

Ocorre que, as agências policiais que fazem parte da criminalização secundária não escolhem pessoas de forma aleatória, essa escolha é feita a partir de outras agências. É nesse momento que entendemos como a mídia é capaz de influir no processo de criminalização.

Na lição do ilustre doutrinador Zaffaroni (2003), essas agências são chamadas de empresas criminalizantes que têm um papel fundamental nesse processo, senão vejamos: 
O conceito de empresário moral (...), na nossa sociedade, pode ser tanto um comunicador social, após uma audiência, um político em busca de admiradores ou um grupo religioso à procura de notoriedade, quanto um chefe de polícia à cata de poder ou uma organização que reivindica os direitos das minorias etc. Em qualquer um dos casos, a empresa moral acaba desembocando em um fenômeno comunicativo: não importa o que seja feito, mas sim como é comunicado. ${ }^{7}$

Dessa forma, podemos perceber que a criminalização midiática, ou seja, a dinâmica na qual a mídia reforça essa seletividade e estigmatização é fator fundamental, tanto para a formação da opinião pública através da agenda setting, quanto como participante efetiva nesse processo de criminalização.

Pode-se dizer que o sistema penal é a representação da política criminal. Isso se dá porque é por meio das decisões no âmbito político que as matérias de controle social e repreensão dos atos criminosos são definidas e traçadas para sua efetivação. Segundo entendimento de Gomes (2015):

$\mathrm{Na}$ indústria comunicacional do espetáculo, a mercantilização do crime - sua conversão em mercadoria noticiosa - produz efeitos que interferem sensivelmente na conformação do sistema penal. São eles: a) o esvaziamento da disposição crítica da massa; b) a canalização do imaginário coletivo para a personificação do inimigo (criminoso); c) a produção de estímulos vitimológicos. ${ }^{8}$

Desse modo, percebemos que o discurso elaborado pelo mass media, sobre os atos criminosos, quase que determina um sistema penal repressivo e instantâneo, não lhe importando que, para isso, seja necessário enfraquecer e/ou flexibilizar garantias tão sensíveis e importantes ao nosso Ordenamento Pátrio.

7 ZAFFARONI, Eugenio Raúl. Direito Penal Brasileiro. Tomo I. Rio de Janeiro: Revan, 2003, p. 45. Apud. MENUCI, Julia Monfardini; FERREIRA, Laura Pinto; MENEGAT, Isabela Costa. A influência da mídia no processo penal. Disponível em < http://egov.ufsc.br/portal/sites/default/files/28225-61308-1-pb.pdf > Acesso em. 02 de abril de 2018.

8 GOMES, Marcus Alan de Melo. Mídia e sistema penal: as distorções da criminalização nos meios de comunicação. $1^{\text {a }}$ ed. - Rio de Janeiro: Revan, 2015. pág. 139 
O processo de industrialização da cultura delineado na primeira metade do século XX e acentuado com a chegada da globalização é determinante, portanto, para entendermos a sociedade na qual participamos hoje. Os meios de comunicação são partes integrantes da sociedade de consumo atual e seria inimaginável entender diferente.

Desde aquele século, até o atual, informar é deter poder e a mídia sabe exatamente o significado disso ao direcionar os assuntos da maneira que mais entende conveniente. Sendo assim, é possível perceber que a mídia e o sistema penal exercem uma verdadeira parceria dentro do capitalismo tardio e essa especial vinculação implica na exacerbação de algumas crenças e, em contrapartida, em "um silêncio sorridente sobre informações que a desmintam. $" 9$

Há quem diga, portanto, que a mídia como a temos hoje, se distanciou da sua função primordial (reportar), para destacar-se como invasora do fato. Os meios de comunicação não mais noticiam, mas opinam. Dessa forma, chega-se à conclusão de que, a opinião pública é, na verdade, a opinião publicada pelos meios de comunicação de massa. ${ }^{10}$

Isso, torna-se uma grande questão quando a influência dos meios comunicacionais na opinião formada pelo público, acaba por afetar o papel do poder judiciário na solução dos conflitos, principalmente penais, de tal forma que o direito penal é constantemente banalizado e acionado como primeira forma de solução. Em consequência, temos um sistema penal formado a partir de uma política criminal midiatizada e irracional.

9 BATISTA, Nilo. Mídia e sistema penal no capitalismo tardio. Disponível em <http://www.bocc.ubi.pt/pag/batista-nilo-midia-sistema-penal.pdf > Acesso em 19 de abril

10 ANDRADE, Fábio Martins de. Mídia e Poder Judiciário - A influência dos órgãos de mídia no

Processo Penal Brasileiro. Rio de Janeiro: Lumen Juris, 2007, pág.47 
Questiona-se, assim, dentro desse trabalho de conclusão, se não seria possível a compatibilização dessa mídia mercantilizada, que se utiliza do espetáculo para transformar o crime em mercadoria barata e instantânea, com uma política criminal preocupada em garantir os direitos fundamentais, em especial o direito a um julgamento criminal justo.

Pretende-se, portanto, com os próximos capítulos, abordar as bases constitucionais em que a mídia se apoia, contrapondo-as com os outros direitos fundamentais que essa acaba, no exercício desvirtuado da função de informar, por violar.

Não somente, se buscará encontrar meios de solução para o conflito entre tais direitos fundamentais tão importantes ao nosso Estado Democrático de Direito, tentando os compatibilizar. 


\section{Capítulo 2. O Princípio Da Liberdade De Expressão E De Informação Na Constituição Federal De 1988.}

\subsection{As Teorias Sobre A Liberdade De Expressão Na Constituição Norte Americana E O Alcance Da Primeira Emenda}

A liberdade de expressão ganhou contexto com a passagem da sociedade medieval (calcada em verdades impossíveis de contestação) para o Iluminismo, onde estavam presentes a capacidade moral e racional dos indivíduos.

Algumas teorias acerca da liberdade de expressão começaram a surgir nos Estados Unidos devido à necessidade de se estabelecer o alcance da Primeira Emenda.

Ao estudarmos essas teorias percebemos que podemos dividi-las em dois grandes grupos, os que entendem que a liberdade de expressão desempenha papel fundamental para a coletividade ou para o Estado Democrático de Direito e aqueles que compreendem tratar-se de um direito individual essencial para a autorrealização pessoal. ${ }^{11}$

$\mathrm{O}$ primeiro grupo entende que deve ser garantida a liberdade de expressão, uma vez que garantir tal direito ocasionará efeitos benéficos ao coletivo. Dessa forma, a garantia da liberdade de expressão não se trata apenas de conferir o direito às pessoas de se expressarem livremente da forma que desejam, mas sim de alcançar um objetivo maior que é a coletividade.

11 SCHREIBER, Simone. A publicidade opressiva de julgamentos criminais - Rio de Janeiro: Renovar, 2008. pág. 50 
Este grupo que defende uma concepção democrática da liberdade de expressão, entende que poderia haver a regulação das empresas de comunicação pelo Estado caso essas causassem interseções indevidas ao exercício da liberdade de expressão e na realização do regime democrático.

Não somente, certos discursos poderiam sofrer restrições de acordo com a sua temática, ou seja, entende-se que discursos que sejam importantes para a formação da opinião pública deverão ser protegidos, preferencialmente, em contrapartida, discursos que não forem interessantes ao interesse público ou que interfiram de maneira negativa na democracia poderiam ser restringidos.

O segundo grupo possui uma concepção não funcional da liberdade de expressão, ou seja, entende que esta é uma forma de autorrealização do homem imprescindível ao seu desenvolvimento e que, estaria, portanto, ligada ao princípio da dignidade humana.

Os que defendem essa posição entendem que não deverá ocorrer qualquer interferência estatal no mercado de comunicação, uma vez que esses ambientes devem ser propícios a uma autonomia individual.

Dessa forma, a liberdade de expressão não estaria vinculada a realização de um bem comum, possuindo uma natureza individual e, por isso, os discursos não deveriam sofrer qualquer tipo de restrição. Excepcionalmente, a liberdade de expressão, por se tratar de um princípio, poderia sofrer restrição caso entrasse em choque com outros princípios. Caso isso viesse a ocorrer recorrer-se-ia ao método de ponderação para resolver este conflito. 
Aquém dessas duas teorias expostas acima temos, também, a teoria da posição preferencial da liberdade de expressão, ou seja, por se tratar de um direito fundamental, de grande relevância para a sociedade, haveria a possibilidade de se colocar firmes balizas, no que diz respeito, às suas restrições. Ressalta-se que, a teoria não tem intenção de atribuir a liberdade de expressão como um direito absoluto, sendo certo que sempre deverá ser feita uma análise casuística.

A posição preferencial da liberdade de expressão na Suprema Corte dos Estados Unidos deu ensejo ao standard do clear present danger test, que tem por essência distinguir o discurso da ação, ou seja, como a liberdade de expressão tem proteção especial dentro da Constituição Norte Americana, entende-se que somente se evidenciado que o discurso levaria a uma ação prejudicial autorizaria, assim, a interferência negativa do Estado. ${ }^{12}$ Para isso, seria necessário distinguir a mera intenção de cometer atos prejudiciais e o efetivo cometimento de tais atos.

Além disso, por se tratar de um direito base para a formação da opinião pública, para o pleno exercício do Estado Democrático e, portanto, para o exercício, em consequência, de outros direitos fundamentais é que se confere à liberdade de expressão uma posição preferencial frente a outros direitos também importantes. Ocorre que, à vista disso, se presume uma diferenciação entre os discursos, de forma que, caso não haja, neles, uma importância pública, não será conferida a eles essa posição preferencial.

12 Ibid. pág. 70 
A doutrina é crítica em relação a essa teoria, tendo em vista que é de extrema dificuldade estabelecer critérios firmes para diferenciar discursos, definindo qual deles é mais ou menos fundamental ao interesse público. Não somente, a dificuldade de se definir o que seria objeto de importância ao interesse público, em um discurso, traz uma clara dificuldade em aplicarmos a teoria na prática.

Podemos perceber diante dessa exposição que a liberdade de expressão é um direito de extrema importância à coletividade e, como tal, pode ser vista de inúmeras óticas diferentes. Dessa forma, dentro de um Estado Democrático de Direito, há quem pretenda limitá-la, há quem pretenda expandi-la, mas não há como extingui-la.

\subsection{A Liberdade De Expressão Na Constituição Federal De 1988}

No Ordenamento Constitucional Brasileiro a liberdade de expressão, também, ganha importante assento. Depois de vinte anos de censura e repressão aos discursos opostos ao regime ditatorial, a democracia precisava respirar e nada mais essencial para cravar o fim de uma ditadura militar do que a possibilidade de se expressar livremente. 
Com isso, percebemos que a Constituição Federal de 1988 instituí o direito à liberdade de expressão como um direito típico de primeira geração, ou seja, aqueles primeiros direitos que foram conquistados pela humanidade. Relacionam-se à luta pela liberdade e segurança diante do Estado tratando-se, portanto, de impor ao Estado uma abstenção, por isso, podem ser igualmente chamados de direitos de dimensão negativa assegurando, assim, aos indivíduos um espaço de liberdade, no qual não se permite interferência estatal. ${ }^{13}$

Os dispositivos que comandam a liberdade de expressão e informação na nossa Carta Magna estão previstos no artigo $5^{\circ}$, incisos IV, V, IX, X, XIV e artigos 220 e $221 .^{14}$

13 FILHO, João. Teoria dos direitos fundamentais. Disponível em < http://www.stf.jus.br/repositorio/cms/portaltvjustica/portaltvjusticanoticia/anexo/joao_trindadade_ _teoria_geral_dos_direitos_fundamentais.pdf >. Acesso em 27 de abril de 2018.

14 Art. $5^{\circ}$ Todos são iguais perante a lei, sem distinção de qualquer natureza, garantindo-se aos brasileiros e aos estrangeiros residentes no País a inviolabilidade do direito à vida, à liberdade, à igualdade, à segurança e à propriedade, nos termos seguintes:

IV - é livre a manifestação do pensamento, sendo vedado o anonimato;

$\mathrm{V}$ - é assegurado o direito de resposta, proporcional ao agravo, além da indenização por dano material, moral ou à imagem;

IX - é livre a expressão da atividade intelectual, artística, científica e de comunicação, independentemente de censura ou licença;

$\mathrm{X}$ - são invioláveis a intimidade, a vida privada, a honra e a imagem das pessoas, assegurado o direito a indenização pelo dano material ou moral decorrente de sua violação;

XIV - é assegurado a todos o acesso à informação e resguardado o sigilo da fonte, quando necessário ao exercício profissional;

Art. 220. A manifestação do pensamento, a criação, a expressão e a informação, sob qualquer forma, processo ou veículo não sofrerão qualquer restrição, observado o disposto nesta Constituição.

$\S 1^{\circ}$ Nenhuma lei conterá dispositivo que possa constituir embaraço à plena liberdade de informação jornalística em qualquer veículo de comunicação social, observado o disposto no art. $5^{\circ}$, IV, $\mathrm{V}, \mathrm{X}, \mathrm{XIII}$ e XIV.

$\S 2^{\circ}$ É vedada toda e qualquer censura de natureza política, ideológica e artística.

$\S 3^{\circ}$ Compete à lei federal:

I - regular as diversões e espetáculos públicos, cabendo ao Poder Público informar sobre a natureza deles, as faixas etárias a que não se recomendem, locais e horários em que sua apresentação se mostre inadequada;

II - estabelecer os meios legais que garantam à pessoa e à família a possibilidade de se defenderem de programas ou programações de rádio e televisão que contrariem o disposto no art. 221, bem como da propaganda de produtos, práticas e serviços que possam ser nocivos à saúde e ao meio ambiente.

$\S 4^{\circ}$ A propaganda comercial de tabaco, bebidas alcoólicas, agrotóxicos, medicamentos e terapias estará sujeita a restrições legais, nos termos do inciso II do parágrafo anterior, e conterá, sempre que necessário, advertência sobre os malefícios decorrentes de seu uso. 
Importante ressaltar que, em que pese a dimensão negativa das normas trazidas, a própria Constituição em seu artigo $220, \S 5^{\circ}$ prevê a possibilidade de combate através de medidas legislativas de monopólios das empresas de comunicação, garantindo, dessa forma, o pluralismo dos meios de comunicação, fator esse, determinante dentro de uma sociedade democrática.

Portanto, é possível afirmarmos que o princípio da liberdade de expressão também possui uma dimensão positiva, ou seja, a imposição ao Estado de criar medidas que estimulem o pluralismo dos meios de comunicação e, também, que combatam eventuais monopólios que prejudiquem esse pluralismo.

As normas referidas tratam dos princípios constitucionais da liberdade de pensamento, de expressão e de informação, garantindo a liberdade de expressão em seu sentido amplo.

Em razão do princípio da liberdade de expressão reunir diversas formas de manifestações expressivas e da impossibilidade de abordarmos profundamente todas elas, o presente trabalho dará especial atenção a liberdade de informação jornalística.

$\S 5^{\circ}$ Os meios de comunicação social não podem, direta ou indiretamente, ser objeto de monopólio ou oligopólio.

$\S 6^{\circ}$ A publicação de veículo impresso de comunicação independe de licença de autoridade.

Art. 221. A produção e a programação das emissoras de rádio e televisão atenderão aos seguintes princípios:

I - preferência a finalidades educativas, artísticas, culturais e informativas;

II - promoção da cultura nacional e regional e estímulo à produção independente que objetive sua divulgação;

III - regionalização da produção cultural, artística e jornalística, conforme percentuais estabelecidos em lei;

IV - respeito aos valores éticos e sociais da pessoa e da família. 


\subsection{Da Liberdade de Informação na Constituição Federal de 1988}

Antes de entrarmos no tema é necessário que façamos a distinção entre liberdade de informação e direito à informação. Este último, a bem da verdade, não é um direito individual ou profissional, mas um direito coletivo garantido a todos. ${ }^{15}$

Por informação podemos entender a "ação ou efeito de informar ou de se informar", assim como, a "reunião dos conhecimentos, dos dados sobre um assunto ou pessoa". ${ }^{16}$ Portanto, podemos afirmar que a liberdade de informação compreende tanto a liberdade de informar, quanto a liberdade de ser informado.

A liberdade de informar corresponderia, ao final, a liberdade de manifestação de pensamento, já a liberdade de ser informado corresponderia ao interesse coletivo, por meio do qual é possível exercermos nossa cidadania firmando o Estado Democrático no qual vivemos.

Com isso, a liberdade de informação da mídia se justifica a partir do momento que as pessoas têm acesso a uma informação correta e imparcial. Dessa forma, além do direito de informar, a mídia possui o dever de informar ao coletivo os fatos e acontecimentos de forma objetiva, sem alterar a verdade ou esvaziar o sentido original, sem isso não termos informação, mas sim deformação. ${ }^{17}$

15 SILVA, José Afonso. Curso de Direito Constitucional Positivo, 37 edição. Pág. 247

16 Dicionário online. Significado de Informação. Disponível em < https://www.dicio.com.br/informacao/ >. Acesso em 30 de abril de 2018.

17 PERIPOLLI, Suzana; DIAS, Monia. Colisão de direitos: Liberdade de imprensa e presunção de inocência. Disponível em <http://coral.ufsm.br/congressodireito/anais/2015/2-9.pdf>. Acesso em 02 de maio de 2018. 
É no artigo $5^{\circ}$, inciso XIV que a Constituição assegura esse direito tão indispensável a realização de um Estado Democrático. Entretanto, apesar deste artigo se referir ao direito de informação em geral, ele tem especial relevância na função do jornalista, uma vez que além de garantir de forma ampla o acesso às informações, também, assenta o direito fundamental do sigilo das fontes, garantia tão cara à prática do jornalismo.

Apesar da garantia do amplo acesso às informações, é possível através do próprio texto constitucional inferir alguns limites a atuação jornalística como a restrição de acesso a fatos relacionados, exclusivamente, à vida privada das pessoas envolvidas, a restrição de acesso as informações detidas por órgãos públicos que sejam imprescindíveis para a segurança da coletividade e do Estado e, também, a restrição a atos processuais dentro do Poder Judiciário que seu sigilo seja motivado por interesse social ou pela defesa da intimidade das partes envolvidas (artigo $5^{\circ}$, inciso LX e artigo 93, inciso IX da Constituição Federal de 1988). ${ }^{18}$

Quanto ao sigilo das fontes não há quem discuta sua posição constitucional, ou seja, tal garantia integra o princípio da liberdade de expressão e, mais diretamente, a liberdade de informação. Ocorre que, apesar dessa garantia expressa no texto constitucional não se trata, consequentemente, de um direito absoluto e, por isso, ao colidir com outros direitos fundamentais poderá ser restringido.

18 SCHREIBER, Simone. A publicidade opressiva de julgamentos criminais - Rio de Janeiro: Renovar, 2008. pág. 106 
O artigo $220, \S^{\circ}$ traz especificamente a liberdade de informação jornalística, mas, também, traz, a essa, ressalvas que devem ser igualmente observadas, como o direito de resposta e reparação do dano material ou o direito à imagem, vedação ao anonimato, entre outros.

Alguns autores entendem que os direitos da personalidade atuariam como limites intrínsecos da liberdade de informação, ou seja, eventuais manifestações que atingissem a honra ou a privacidade da pessoa retratada não seriam protegidas pelo direito constitucional da liberdade de informação e, portanto, se quer haveria colisão de direitos fundamentais, pois não haveria proteção dessas manifestações pela norma constitucional garantidora da liberdade de informação. ${ }^{19}$

Entretanto, segundo Simone Schreiber, trata-se, o artigo 220, $\S 1^{\circ}$, de norma-princípio, o que significa dizer que devemos primeiro identificar o conteúdo da liberdade de informação jornalística delimitando, assim, o âmbito da proteção do direito (em um primeiro momento essa delimitação deverá ser feita da forma mais ampla possível) e, após, devemos fixar limites externos com o fim de conformar o direito tratado com outros direitos de igual importância trazidos por nossa Carta Magna. A solução será dada, ao final, através da proporcionalidade, onde serão sopesados os direitos colidentes a partir da técnica de ponderação. ${ }^{20}$

19 ANDRADE, José Carlos Vieira de. Os direitos fundamentais na Constituição Portuguesa de 1976. Coimbra: Almedina, 2001, p.285. Apud. SCHREIBER, Simone, pag. 110-111.

20 SCHREIBER, Simone. Op. Cit. pág. 111-112. 
Portanto, em que pese alguns autores entenderem que os limites à liberdade de informação estariam contidos dentro do próprio enunciado do artigo $220, \S 1^{\circ}$, não julgo ser este o entendimento mais acertado, tendo em vista que é possível que a liberdade de informação venha a colidir com outros direitos fundamentais que não estão ali enumerados, mas que são tão importantes para a Constituição Federal quanto aqueles que estão, como o direito a um julgamento criminal justo - tema deste trabalho.

Dessa forma, entende-se que, ao enumerar tais direitos no artigo, o legislador originário queria apenas ilustrar potenciais conflitos entre direitos fundamentais sem ter a pretensão de limitar esse âmbito e, muito menos, estabelecer hierarquia entre esses direitos.

Certo é que, apesar da verdadeira importância deste direito para a realização da efetiva democracia, a liberdade de informação faz parte do contexto das liberdades públicas e, por isso, não é o único direito ou interesse protegido pela Constituição de $1988 .{ }^{21}$

Por isso, como veremos a seguir, a própria Constituição prevê em seu texto a presença de mecanismos que buscam assegurar tanto o direito à liberdade de informação e expressão, quanto outros direitos que possam ser violados no exercício dessas liberdades.

\subsubsection{Da Vedação da Censura}

21 SOARES, Fábio. Liberdade de comunicação. Proibição de censura e limites. Disponível em < http://www.emerj.tjrj.jus.br/serieaperfeicoamentodemagistrados/paginas/series/11/normatividadeju ridica_60.pdf>. Acesso em 04 de maio de 2018. 
Censura, segundo Luís Roberto Barroso, é "a submissão à deliberação de outrem do conteúdo de uma manifestação de pensamento, como condição prévia de sua veiculação."22

Com o fim de anos de uma ditadura militar no Brasil se fez necessário, dentro da nossa Constituição, o reforço de alguns pilares da Democracia. Dessa forma, o legislador constituinte deu especial atenção para as liberdades efetivas e, por isso, em dois momentos distintos (tanto no artigo $5^{\circ}$, inciso IX, quanto o artigo 220, $\S 2^{\circ}$ da Constituição) reforçou a questão da vedação a censura. Luís Roberto Barroso, assim, também afirma, vejamos:

Uma nova Constituição, ensina a doutrina clássica, é uma reação ao passado e um compromisso com o futuro. A Constituição brasileira de 1988 foi o ponto culminante do processo de restauração do Estado democrático de direito e da superação de uma perspectiva autoritária, onisciente e não pluralista do exercício do poder. (...). Nesta nova ordem, a garantia da liberdade de expressão, em suas múltiplas formas, foi uma preocupação constante do constituinte, que a ela dedicou um conjunto amplo de dispositivos, alguns deles superpostos. Rejeitava-se, da forma mais explícita possível, o modelo anterior (...). É possível constatar que vige no País ampla liberdade de expressão, estando proibida a censura sob qualquer forma. 23

22 BARROSO, Luís Roberto. "Liberdade de Expressão, Censura e Controle da Programação de Televisão na Constituição de 1988". In Temas de Direito Constitucional. Rio de Janeiro: Renovar, 2002, p. 347, Apud. SOARES, Fábio. Liberdade de comunicação. Proibição de censura e limites. Disponível em <http://www.emerj.tjrj.jus.br/serieaperfeicoamentodemagistrados/paginas/series/11/normatividade juridica_60.pdf $>$. Acesso em 04 de maio de 2018.

23 BARROSO, Luís Roberto. "Liberdade de Expressão, Censura e Controle da Programação de Televisão na Constituição de 1988”. In Temas de Direito Constitucional. Rio de Janeiro: Renovar, 2002, p. 354-356.Apud. SOARES, Fábio. Liberdade de comunicação. Proibição de censura e limites. Disponível em <http://www.emerj.tjrj.jus.br/serieaperfeicoamentodemagistrados/paginas/series/11/normatividade juridica_60.pdf >. Acesso em 04 de maio de 2018. 
De forma geral, as normas trazem a proibição de controle prévio por órgãos estatais sobre as manifestações expressivas. Entretanto, a censura prévia não é a única a merecer especial atenção, já que o estabelecimento de restrições posteriores a manifestação expressiva poderá ser tão prejudicial, ou mais, as liberdades de comunicação.

Em razão da necessidade de se resguardar outros direitos de igual proteção constitucional, a Constituição prevê mecanismos de reparação civil e criminal às lesões causadas no exercício da liberdade de expressão. Porém, esses mecanismos se utilizados de forma desarrazoada podem se tornar, também, uma forma de censura não desejada pelo texto constitucional.

Ressalta-se ainda, assim, que, ocorrendo o conflito entre dois ou mais direitos, igualmente, garantidos pela nossa Constituição poderá ser vedada a publicação da mensagem. Dessa forma, existem dois tipos de vedação de publicação, a temporária, ou seja, quando há a postergação da publicação da mensagem e a definitiva, ou seja, quando há a supressão total da mensagem que não chegará ao conhecimento do público em momento algum.

Trata-se de um tema vasto e que, por isso, não se tem a pretensão de esgotá-lo com o presente trabalho, porém, para efeitos práticos, a vedação temporária da publicação da mensagem em casos de notícias envolvendo julgamentos criminais em andamento, principalmente aqueles que têm especial atenção da opinião pública e, portanto, da mídia, seria uma possível solução para tentar garantir um ambiente adequado para um julgamento justo que não importaria em censura e que, portanto, não seria vedada pela nossa Carta Magna. 


\subsubsection{Do Direito de Resposta}

O direito de resposta é previsto na Constituição de 1988 em seu artigo $5^{\circ}$, inciso $\mathrm{V}^{24}$, como um instrumento capaz de viabilizar a reparação de direitos constitucionalmente protegidos que foram violados pelo mau exercício da liberdade de expressão.

Antigamente esse direito era regulado pela Lei de Imprensa $n^{\circ}$ 5250/67. Ocorre que, após o julgamento da Arguição de Descumprimento de Preceito Fundamental $\mathrm{n}^{\mathrm{o}} 130$ no Supremo Tribunal Federal, reconheceu-se a incompatibilidade dessa com a Constituição Federal de 1988.

O Supremo Tribunal Federal no julgamento da Arguição de Descumprimento de Preceito Fundamental $n^{\circ} 130$ criou balizas essenciais a essa garantia que facilitaram o trabalho do intérprete do direito e do próprio legislador.

24 Art. $5^{\circ}$ Todos são iguais perante a lei, sem distinção de qualquer natureza, garantindo-se aos brasileiros e aos estrangeiros residentes no País a inviolabilidade do direito à vida, à liberdade, à igualdade, à segurança e à propriedade, nos termos seguintes: V - é assegurado o direito de resposta, proporcional ao agravo, além da indenização por dano material, moral ou à imagem; 
Entendeu, dessa forma, que (1) trata-se de uma garantia que se encontra em conformidade com a liberdade de imprensa, (2) que independe de regulação infraconstitucional por se tratar de norma de eficácia plena e aplicação imediata, (3) que constitui junto as reparações civis e persecução penal, um mecanismo frente ao exercício abusivo da liberdade de imprensa, (4) que possui natureza transindividual, ou seja, protege a honra do ofendido, ao mesmo tempo que potencializa o direito à informação, (5) que pressupõe a ocorrência de informação não verdadeira ou equivocada e (6) que depende da ampla produção de provas para que se constate o erro na veiculação jornalística e se viabilize o direito de resposta. ${ }^{25}$

Em 2015, portanto, foi sancionada a Lei 13.188/2015 que tem por objeto a regulação do direito de resposta constitucionalmente reconhecido por nossa Constituição. Ocorre que, alguns artigos da atual lei se desviaram de algumas balizas e importaram em cerceamento indevido à liberdade de imprensa e, em razão disso, esses artigos sofreram ações direitas de inconstitucionalidade que devem ser acompanhadas, uma vez que podem mudar novamente o rumo desse direito.

Não cabe neste trabalho estudarmos todas as vertentes do direito de resposta e nem fazer uma análise mais profunda do tema, sendo apenas necessário, em linhas gerais, trazer esse direito como uma eventual solução aos conflitos entre a liberdade de informação e de expressão e outros direitos constitucionalmente garantidos como a honra, imagem e, principalmente, o tema deste trabalho, o direito a um julgamento criminal justo.

25 FERNANDES, Marcelo. A nova lei sobre direito de resposta e a liberdade de imprensa. Disponível em < http://www.migalhas.com.br/dePeso/16,MI239139,51045-

A+nova+lei+sobre+direito+de+resposta+e+a+liberdade+de+imprensa $>$. Acesso em 08 de maio de 2018. 
É importante pensarmos no direito de resposta, portanto, como um instrumento capaz de viabilizar o acesso do público as mais vastas informações que serão utilizadas, ao fim, no exercício do autogoverno, uma vez que, por muitas vezes, é este direito que permite o esclarecimento do público sobre os fatos e questões de interesse de toda a sociedade.

Segundo Nilo Batista, existem casos em que todo o processo se desenvolve dentro dos meios de comunicação, sendo assim, se deveria exigir da mídia o que é exigido nos Tribunais, obediência ao contraditório. Afirma este que, hoje em dia, após longa veiculação da versão desenvolvida pela acusação há apenas uma singela manifestação, diga-se de passagem, ridicularizada pela mídia, do acusado ou de seu advogado. Portanto, já que o processo tem o seu desenrolar nos meios de comunicação que, ao menos, sejam dadas as partes paridade de armas. ${ }^{26}$

Dessa forma, o acesso aos meios de comunicação deveria ser alargado aumentando a qualidade do debate público, seja por meio do direito de resposta, seja por outro mecanismo que gerasse a diversidade de informações e opiniões veiculadas ao público.

26 BATISTA, Nilo. A Corte Europeia já pune "publicidade opressiva" como a usada contra Lula. Disponível em <https://www.viomundo.com.br/denuncias/nilo-batista-corte-europeia-ja-punepublicidade-opressiva-como-a-usada-contra-lula.html>. Acesso em 10 de maio de 2018. 
Gustavo Binenbojm, por sua vez, propõe a criação de um ente regulador, de composição plural e não governamental, com o poder para determinar inclusão de fatos e versões, o que implicaria em relativização da autonomia editorial, mas realizaria mais amplamente os princípios constitucionais pertinentes à comunicação social, já que a Carta de 1988 não consagra a liberdade de expressão apenas como um direito negativo, senão vejamos:

A meu ver, portanto, o direito de resposta deve ser visto como um instrumento de mídia colaborativa em que o público é convidado a colaborar com suas próprias versões de fatos e apresentar seus próprios pontos de vista. A autonomia editorial, a seu turno, seria preservada desde que seja consignado que a versão ou comentário é de autoria de um terceiro e não representa a opinião do veículo de comunicação. ${ }^{27}$

Essa, a meu ver, é uma ótima forma para enxergar o direito de resposta, tendo nele, não apenas como um instrumento do ofendido para refutar uma informação não verídica circulada pelos grandes meios de comunicação, mas de uma sociedade toda que ganhará com a diversidade de informação.

Assim, quem sabe, o direito de resposta ao ser ampliado, nos moldes como propõe o autor supracitado, permitiria que diferentes visões de uma mesma informação chegassem ao conhecimento do público e permitiria uma maior reflexão crítica capaz de gerar uma real opinião pública e não uma opinião publicada, como temos hoje.

\subsection{A Jurisprudência Nos Tribunais Acerca Do Princípio Da Liberdade De Expressão E Informação Em Colisão Com Outros Direitos Fundamentais.}

27 BINENBOJM, Gustavo. Meios de comunicação de Massa, Pluralismo e Democracia Deliberativa: as liberdades de expressão e imprensa nos Estados Unidos e no Brasil. Revista da Escola de Magistratura do Estado do Rio de Janeiro. Vol.6, nº23, 2003, p.375. Apud. SCHREIBER, Simone.

A publicidade opressiva de julgamentos criminais. Rio de Janeiro: Renovar, 2008. pág. 118. 
Com o fim de elucidar o tema sobre liberdade de expressão e informação dentro da ótica constitucional de 1988 se faz imprescindível trazer, ao trabalho, julgados que demonstram como os Tribunais do país vêm entendendo e decidindo acerca das potenciais colisões entre direitos fundamentais.

O Supremo Tribunal Federal em decisão na Arguição de Descumprimento de Preceito Fundamental $n^{\circ}$ 130, que julgou a incompatibilidade da Lei de Imprensa com a Constituição, firmou entendimento no sentido de que a liberdade de expressão possui uma posição preferencial no Estado Democrático brasileiro por ser uma pré-condição para o exercício efetivo dos demais direitos e liberdade. Dessa forma, na ocorrência de uso abusivo deste direito a reparação deveria se dar, preferencialmente, por meio de retificação, direito de resposta ou indenização. ${ }^{28}$

Em que pese esse entendimento é importante ressaltar, mais uma vez, que não se está conferindo a liberdade de expressão e informação valor absoluto. Ainda que se confira uma precedência axiológica a liberdade de expressão frente aos direitos de personalidade, há a possibilidade de que esta sofra restrições em situações de colisão com outros direitos fundamentais de igual hierarquia como, por exemplo, o direito a um julgamento justo e imparcial.

28 STF, Medida cautelar na Rcl. N 22328, Ministro Luís Roberto Barroso, Brasília, 20 de novembro. 2015. Disponível em < http://www.luisrobertobarroso.com.br/wpcontent/uploads/2015/11/Liberdade-de-expressao-Rcl-22328-1.pdf $>$. Acesso em 10 de maio de 2018. 
Foram, a partir da pesquisa jurisprudencial realizada, selecionados os seguintes julgados: 1. Ap. Cível no 70073985319 - TJ-RS, Relator: Túlio de Oliveira Martins, data do julgamento 28/09/2017, Décima Câmara Cível, data da publicação: Diário da Justiça do dia 06/10/2017 - Indenização por danos morais por abuso do exercício da liberdade de expressão, em virtude de reprodução de imagem publicada em notícia de jornal; ${ }^{29} 2$. Ap. Cível $\mathrm{n}^{\circ}$ 00567632820148190001 - TJ-RJ, Relator: Horácio dos Santos Ribeiro Neto, data do julgamento 14/03/2017, Vigésima Segunda Câmara Cível, data da publicação: 16/03/2017 - Liberdade de Imprensa x Direito à honra e imagem Anthony Garotinho x Editora Globo S.A ${ }^{30}$; 3. Recurso Especial no 984.803 ES (2007/0209936-1) - Relatora: Ministra Nancy Andrighi, data do julgamento: 26 de maio de 2009 - Necessidade de demonstrar a falsidade da notícia ou inexistência de interesse público. Ausência de culpa. Liberdade de imprensa exercida de modo regular, sem abusos ou excessos. ${ }^{31}$

29 TJ-RS, Ap. Cível no 70073985319, Rel. Des. Túlio de Oliveira Martins. Porto Alegre, 28 de setembro. 2017. Disponível em < https://tj-rs.jusbrasil.com.br/jurisprudencia/507432858/apelacaocivel-ac-70073985319-rs/inteiro-teor-507432895?ref=juris-tabs > Acesso em 08 de maio de 2018.

30 TJ-RJ, Ap. Cível n ${ }^{\circ} 00567632820148190001$, Rel. Des. Horácio dos Santos Ribeiro Neto. Rio de Janeiro, 14 de março. 2017. Disponível em < https://tj-

rj.jusbrasil.com.br/jurisprudencia/442574378/apelacao-apl-567632820148190001-rio-de-janeirocapital-22-vara-civel >. Acesso em 08 de maio de 2018.

31 STJ, Resp. nº 984803, Rel. Ministra Nancy Andrighi. Brasília, 26 de maio. 2009. Disponível em < https://ww2.stj.jus.br/processo/pesquisa/? $\mathrm{src}=1.1 .2 \&$ aplicacao=processos.ea\&tipoPesquisa=tipoPesquisaGenerica\&num_registro=20070209 9361 >. Acesso em 08 de maio de 2018. 
1. No primeiro caso, a Apelação Cível $n^{\circ} 70073985319$, consiste no ajuizamento de ação por danos morais de Marcelo Paintinger de Figueiredo em face de Eliton José, uma vez que este haveria publicado em sua página pessoal em rede social (Facebook) uma imagem do autor saindo algemado de uma delegacia com uma frase depreciativa em relação à sua honra. Ocorre que, essa imagem havia sido publicada em reportagem do Jornal Hora de Santa Catarina, dessa forma, a imagem reproduzida pelo réu foi captada em ambiente público. O desembargador em seu voto afirma que, "as crônicas policias são de interesse público eis que publicadas no intuito de levar ao conhecimento da população fato envolvendo um crime (...)" e que, por isso, não vislumbrava abuso da liberdade de expressão quanto a reprodução praticada pelo réu, o que não acarretaria sequer o direito de indenização.

Percebemos, portanto, que quando se trata de fotos obtidas em âmbito público, os Tribunais tendem a se manifestar no sentido de não haver abuso na liberdade de expressão, em sentido amplo, neste caso se refletindo na liberdade de informação.

Dessa forma, há, nesses casos, a preferência à liberdade de expressão e informação do que outros direitos fundamentais como a honra, intimidade. 
2. O segundo caso trata da Apelação Cível no 00567632820148190001 , consistente na ação de indenização por danos morais ajuizada por Anthony Garotinho e outros em face da Editora Globo S.A e outra. Afirma aquele que, os réus publicaram matéria de jornal, em seu sítio eletrônico, imputando-lhe falsas acusações. Neste episódio afirmam os autores que, os réus os acusaram de, em conluio com ex-chefe de Polícia Civil, Álvaro Lins, usar de ameaça, de perseguição, de intimidação, de espionagem e da produção de dossiês para desacreditar a política de pacificação do Rio de Janeiro efetivada por meio das UPP'S. Argumentaram, assim, os autores que essas acusações seriam desprovidas de provas.

Em seu voto, o desembargador, afirmou que a matéria elaborada e veiculada pelos réus foi de cunho informativo - apenas narrando fatos contidos em documentos oficiais, bem como as informações tinham sido extraídas do blog mantido pelo próprio autor. Dessa forma, afirmou que os réus basearamse em fontes regulares e, apenas, exerceram o direito constitucionalmente garantido de liberdade de informação.

Não somente, afirma o desembargador que, os réus teriam cumprido o dever de informar os fatos relevantes à sociedade, sem emitir juízo de valor, ressaltando, outrossim, que o autor é deputado federal, pessoa pública e por esta razão o interesse público, do que se reveste a divulgação de informações que envolvam o autor ou relatem eventual comportamento incompatível com o cargo de representação popular deverá prevalecer. Portanto, considerou que não houve nenhum abuso ao direito de liberdade de expressão exercido pelos réus. 
Com isso, percebemos que, em se tratando de fontes regulares, informações provenientes de documentos oficiais com provas dos fatos e de pessoa pública (o que aumenta o interesse público por informações) há a preferência da liberdade de expressão face a outros direitos constitucionalmente previstos.

3. O terceiro julgado consiste no Recurso Especial de $\mathrm{n}^{\circ} 984.803$ ajuizado por Globo Comunicações e Participações S/A, em razão da ação de reparação por danos morais e materiais proposta por Hélio de Oliveira Dorea, uma vez que aquela teria veiculado reportagem no programa Fantástico em maio de 2002 sobre suposta corrupção na Prefeitura de São Gonçalo (RJ) afirmando, esse, que não estaria envolvido nos fatos.

A Ministra em seu voto, afirmou que:

(...)a liberdade de informação deve estar atenta ao dever de veracidade, pois a falsidade dos dados divulgados manipula em vez de formar a opinião pública, bem como ao interesse público, pois nem toda informação verdadeira é relevante para o convívio em sociedade.

Portanto, segundo o entendimento manifestado pela ministra, a honra e a imagem dos cidadãos não são violadas quando se divulgam informações verdadeiras e fidedignas e que, além disso, são do interesse público.

Além disso, no presente caso, a reportagem foi sustentada com base no depoimento de fontes fidedignas, sendo ouvido, também, o Autor da ação, por meio de seu advogado, demonstrando a atuação diligente da Globo ao veicular a reportagem. Dessa forma, entendeu a ministra que não haveria violação da honra do autor e, por isso, deu provimento ao Recurso Especial, dando, como podemos observar, preferência para a liberdade de expressão e informação. 
Percebe-se, assim que, quando há interesse público, além de fontes fidedignas e um esforço diligente por parte das empresas de comunicação em buscar a verossimilhança da reportagem com os fatos, há a preferência da liberdade de expressão e informação sobre outros direitos constitucionalmente protegidos.

Ainda neste tópico incumbe ressaltar que, quando os Tribunais não dão preferência o direito de liberdade de expressão e informação, realizando com isso atos de censura, o STF em sede de Reclamação Constitucional reforma as decisões dando preferência aos direitos de liberdade de expressão e informação, conforme percebemos nas Reclamações $N^{\circ} 18638^{32}$ e $22328 .{ }^{33}$

Não somente, até nos casos em que há o abuso do direito de liberdade de expressão e informação, os Tribunais, em regra, não se utilizam da censura posterior, mas sim da atribuição de indenização por dano moral, conforme orientação do Supremo Tribunal Federal na Arguição de Descumprimento de Preceito Fundamental No 130.

Quanto a isso, deve-se ter cuidado com o arbitramento dessas indenizações sob pena de caracterizar formas de censura, desestimulando os meios de comunicação a fornecer informações importantes à sociedade por medo de sofrerem punições severas.

32 STF, Rcl. No 18638, Rel. Ministro Luís Roberto Barroso, Brasília, 2 de maio. 2018. Disponível em < https://stf.jusbrasil.com.br/jurisprudencia/574029873/reclamacao-rcl-18638-ce-ceara-9998385$2220141000000>$ Acesso em 10 de maio de 2018.

33 STF, Medida cautelar na Rcl. N 22328, Ministro Luís Roberto Barroso, Brasília, 20 de novembro. 2015. Disponível em < http://www.luisrobertobarroso.com.br/wpcontent/uploads/2015/11/Liberdade-de-expressao-Rcl-22328-1.pdf >. Acesso em 10 de maio de 2018. 
Com isso, significa dizer que, ainda que o Supremo Tribunal Federal confira posição preferencial a liberdade de expressão, ao reconhecer a possibilidade de imputar indenizações posteriores quando verificado o excesso no exercício desse direito que interfira em outros igualmente protegidos pela Constituição, estaria se afastando da orientação norte-americana, uma vez que no standard do clear and present danger criado por Oliver Wendell Holmes, juiz da Suprema Corte nos Estados Unidos, a liberdade de expressão não poderia ser restringida nem quando envolvesse incitação ou apologia a ações ilegais, muito menos quando o discurso é desagradável ou ofensivo à maioria da comunidade. ${ }^{34}$

34 NAPOLITANO, Carlo. Liberdade de imprensa no Supremo Tribunal Federal: Análise comparativa com a Suprema Corte dos Estados Unidos. Disponível em < http://www.scielo.br/pdf/interc/v38n1/1809-5844-interc-38-01-0019.pdf >. Acesso em 10 de maio de 2018. 


\section{Capítulo 3. O Direito A Um Julgamento Criminal Justo E Os Reflexos No Princípio Da Presunção De Inocência}

\subsection{O Princípio Do Devido Processo Legal - Julgamento Criminal Justo - Na Constituição Federal De 1988}

O princípio do devido processo legal, de origem inglesa, associada a Magna Carta de 1215, integrou-se à Constituição americana no ano de 1791. Este princípio desde o início foi marcado por fortes disputas políticas que, ao final, moldaram seu significado atual na Constituição norte-americana e que, também, foram responsáveis por firmar o entendimento que esse princípio possui em nossa Constituição Federal. ${ }^{35}$

Em nossa Constituição, o princípio do devido processo legal encontra-se enunciado no artigo $5^{\circ}$, inciso LIV, que traz como texto o seguinte: "ninguém será privado da liberdade ou de seus bens sem o devido processo legal. " Tratase de uma norma-princípio, uma vez que descreve a realização de um fim e não um comportamento, o que a difere das regras que descrevem um comportamento em seu enunciado.

O devido processo legal tem como finalidade possibilitar o maior e mais amplo controle dos atos jurídicos estatais. Não somente, objetiva a proteção de outros direitos fundamentais que, também, estão dispostos em nossa Carta Magna, seja de maneira explicita ou implícita.

35 SCHREIBER, Simone. A publicidade opressiva de julgamentos criminais - Rio de Janeiro: Renovar, 2008. pág. 155-157. 
Dessa forma, esse princípio visa estabelecer limites para atuação estatal, ou seja, não se proíbe que o Estado, através de seus órgãos, ao atuar em prol do público, imponha restrições aos bens individuais constitucionalmente protegidos, entretanto, ao fazê-lo, é necessário que seja por meio de um processo justo, observando-se o devido processo legal e evitando decisões arbitrárias - tomadas aos caprichos de quem tem o poder em mãos.

Existem elementos extraídos do presente princípio que são exclusivos em matéria penal, isso porque a relação travada no processo penal, entre Estado e indivíduo (réu), é desigual e, portanto, merece especial atenção. Esse princípio, dessa forma, visa garantir o julgamento criminal justo, protegendo o acusado contra qualquer arbitrariedade praticada pelo Estado.

Ademais, é por meio do devido processo legal que outros princípios são interpretados, como a ampla defesa, contraditório, vedação da prova ilícita, etc. Ao final se estabelece uma relação dialética em que a explicitação do que compõe esses outros princípios também auxilia na compreensão da aplicação do devido processo legal. ${ }^{36}$

Apesar da dialética entre o devido processo legal e os outros princípios dispostos na constituição federal de 1988, a jurisprudência aplica aquele princípio sem vinculá-lo aos princípios correlatos, uma vez que a ideia é, justamente, estabelecer um processo justo o que, ao final, é o que este princípio visa.

36 Ibid. pág. 175. 
A doutrina também afirma a flexibilização do conteúdo do princípio estudado permitindo que se extraia dele sempre uma maior proteção do indivíduo diante do Estado. Entretanto, a criação de standards visando as situações possíveis de aplicação do princípio densificam a norma e asseguram de maneira mais efetiva a proteção prometida por esta. ${ }^{37}$

\subsection{O princípio da presunção de inocência}

Foi na Declaração de Direitos do Homem e do Cidadão, no ano de 1789, que o princípio da presunção de inocência, pela primeira vez, foi efetivado. Em seguida, a Declaração Universal de Direitos do Homem, da Organização das Nações Unidas, em 1948 o recepcionou. ${ }^{38}$

No Brasil, a Constituição Federal trouxe, somente em 1988, em seu artigo $5^{\circ}$, inciso LVII, um dos princípios chaves para o processo penal, o princípio da presunção de inocência.

Afirma o princípio que, "ninguém será considerado culpado até o trânsito em julgado de sentença penal condenatória”. Em que pese atual entendimento do Supremo Tribunal Federal sobre a antecipação da execução da pena, contrariando o texto expresso da lei constitucional, não se trata, este trabalho, de discutir esse entendimento. Dessa forma, importante ressaltar que, apesar de conhecer a atual discussão, ela não será objeto deste estudo.

37 Ibid. pág. 186.

38 PERIPOLLI, Suzana; DIAS, Monia. Colisão de direitos: Liberdade de imprensa e presunção de inocência. Disponível em < http://coral.ufsm.br/congressodireito/anais/2015/2-9.pdf >. Acesso em 02 de maio de 2018. 
Alguns doutrinadores afirmam que este artigo não traria o princípio da presunção de inocência, pois não há no texto constitucional que todo homem se presumirá inocente, em contrapartida, o texto ao afirmar que ninguém será considerado culpado traria o princípio da desconsideração prévia de culpabilidade que seria de aplicação mais restrita. ${ }^{39}$

Apesar disso, as jurisprudências dos tribunais superiores tratam as expressões presunção de inocência e desconsideração prévia de culpabilidade como sinônimas, dessa forma, não se impõe restrições para aplicação do princípio.

Aury Lopes Jr. afirma que, a presunção de inocência impõe um verdadeiro dever de tratamento, isso porque exige que o réu seja tratado como inocente. Tal dever, por sua vez, atua em duas dimensões, a interna e a externa ao processo. ${ }^{40}$

Segundo o mesmo autor, a dimensão interna seria um dever de tratamento imposto em primeira mão ao juiz, impondo que o dever probatório seja da acusação, já que se o réu é considerado inocente não deverá ser imposto a ele o ônus probatório. Além disso, em caso de dúvida a absolvição do réu se impõe (caracterizando o in dúbio pro reo, que nada mais é do que uma regra extraída do princípio da presunção de inocência).

39 SCHREIBER, Simone. Op. Cit. pág. 187.

40 LOPES JR., Aury. Direito processual penal. - 12. ed. - São Paulo: Saraiva, 2015. pág. 93-94. 
Ademais, ainda dentro da dimensão interna, se encontrariam as restrições ao uso das prisões cautelares, ou seja, todas as medidas restritivas ou coercitivas que se façam necessárias no caminhar do processo devem ser aplicadas quando de extrema necessidade e dentro de uma medida exata que não venha a se transformar em abuso.

Já quanto a dimensão externa afirma este autor que, a presunção de inocência exige uma proteção contra a publicidade opressiva e a estigmatização prematura do réu. Portanto, a presunção de inocência deve ser usada como verdadeiro limite democrático à abusiva exploração dos meios de comunicação em torno do fato criminoso e do próprio processo judicial. Afirma, assim, que, "o bizarro espetáculo montado pelo julgamento midiático deve ser coibido pela eficácia da presunção de inocência. " ${ }^{41}$

Sendo assim, o princípio constitucional estudado é uma das mais importantes garantias previstas na Constituição, uma vez que o acusado pela prática de uma infração penal deixa de ser um simples componente de uma relação jurídica processual e torna-se um sujeito detentor de direitos e garantias. Além disso, esse princípio busca afastar as arbitrariedades praticadas pelo poder público em vista de uma resposta rápida para a sociedade funcionando como um verdadeiro limite constitucional. ${ }^{42}$

41 LOPES JR., Aury. Direito processual penal. - 12. ed. - São Paulo: Saraiva, 2015. pág. 94

42 FERRARI, Rafael. O princípio da presunção de inocência como garantia processual penal. Disponível em < http://www.ambitojuridico.com.br/site/?n_link=revista_artigos_leitura\&artigo_id=11829 >. Acesso em 13 de maio de 2018. 
Ocorre que, nem sempre essas dimensões são observadas pelo judiciário brasileiro. Embora seja admitida a necessidade de se afirmar a utilização do princípio da presunção de inocência como norteador do processo penal, em muitos são os casos em que o judiciário relativiza esse princípio, manifestamente, influenciado pela mídia opressiva e sua opinião pública(da).

Nilo Batista em seu texto "Mídia e sistema penal no capitalismo tardio, afirma que:

Tensões graves se instauram entre o delito-notícia, que reclama imperativamente a pena-notícia, diante do devido processo legal (apresentado como um estorvo), da plenitude de defesa (o locus da malícia e da indiferença), da presunção de inocência (imagine-se num flagrante gravado pela câmera!) e outras garantias do Estado democrático de direito, que só liberarão as mãos do verdugo quando o delito-processo alcançar o nível do delito-sentença (= pena notícia). Muitas vezes essas tensões são resolvidas por alguns operadores - advogados, promotores ou juízes mais fracos e sensíveis a boa imagem - mediante flexibilização e cortes nas garantias que distanciam o delito-notícia da pena-notícia. ${ }^{43}$

É sabido, portanto, que, em inúmeros casos, erros judiciários foram cometidos ao se flexibilizar o princípio da presunção de inocência. O Poder Judiciário, por sua vez, acaba cedendo ao populismo penal, que explora o medo para alcançar um maior rigor penal como forma de solucionar a criminalidade.

Dessa forma, decisões são tomadas com base em um clamor social por segurança pública que é, muitas das vezes, equivocado e distorcido pela mídia formadora da opinião pública.

43 BATISTA, Nilo. Mídia e sistema penal no capitalismo tardio. Disponível em <http://www.bocc.ubi.pt/pag/batista-nilo-midia-sistema-penal.pdf> Acesso em 19 de abril 
Luís Roberto Barroso entende que o papel do Poder Judiciário não poderia estar a serviço da opinião pública, uma vez que este deveria representar um papel contramajoritário, por excelência, vejamos:

Embora deva ser transparente e prestar contas à sociedade, o Judiciário não pode ser escravo da opinião pública. Muitas vezes, a decisão correta e justa não é a mais popular. Nessas horas, juízes e tribunais não devem hesitar em desempenhar um papel contra-majoritário. $\mathrm{O}$ populismo judicial é tão pernicioso à democracia como $\mathrm{O}$ populismo em geral. ${ }^{44}$

Ocorre que isso não acontece, como veremos a seguir. Os dois casos que serão abordados, no presente trabalho, demonstram, com clareza, a influência opressiva da mídia nas decisões do processo criminal e os reflexos causados no princípio da presunção de inocência. Um no âmbito do Tribunal do Júri e o outro no âmbito do Poder Judiciário - juízes togados.

\subsubsection{O Caso Do Goleiro Bruno E Eliza Samúdio}

O caso do goleiro do Flamengo, Bruno Fernandes e da modelo Eliza Samúdio, demonstra, claramente, a influência da mídia nos julgamentos criminais e a capacidade que esta tem em mitigar o princípio da presunção de inocência.

44 BARROSO, Luís Roberto. Curso de direito constitucional contemporâneo: os conceitos fundamentais e a construção do novo modelo/Luís Roberto Barroso. - 4 ed. - São Paulo: Saraiva, 2013. Pág. 443-444 
Em 2009 Eliza Samúdio, modelo e atriz pornográfica, anunciou publicamente à mídia que estaria grávida do, então, goleiro do Flamengo, Bruno Fernandes. Este, por sua vez, não aceitava e nem reconhecia a paternidade. No mesmo ano, a modelo foi a delegacia noticiar que teria sofrido ameaças, sido espancada, colocada em cárcere privado e obrigada a tomar remédios abortivos, tudo, como ela alegou, a mando de Bruno.

O bebê nasceu em fevereiro de 2010 e, até então, o goleiro não aceitava a paternidade. Em junho de 2010 com o desaparecimento de Eliza Samúdio, Bruno foi considerado o principal suspeito. Por se tratar de uma figura pública o caso acabou sendo maciçamente publicado e acompanhado pela mídia.

A mídia, por sua vez, atuou mostrando uma sequência atualizada dos fatos, levantando hipóteses de onde se encontraria o corpo da atriz e modelo, com isso, levou a população acompanhar o caso como se fosse uma verdadeira série investigativa.

O programa "A tarde é sua", do canal Rede TV, apresentado pela jornalista Sônia Abrão, expôs o caso, insistentemente, através da divulgação sequencial e intensa dos personagens principais.

Não somente, o programa "Fantástico" veiculado pela Rede Globo conseguiu, antes mesmo das autoridades policiais, entrevista com o primo do goleiro, na época dos fatos, menor de idade, que afirmou que Eliza teria sido levada até o sítio do goleiro, em Minas Gerais, e lá teria sido esquartejada e entregue a cachorros da raça rottweiler, tudo sob o comando de Bruno. Este, a partir dessa divulgação, passou a ser chamado pela mídia de assassino frio e cruel. 
Percebemos, portanto, o quanto que a mídia é capaz de influenciar em um julgamento, tendo em vista que a primeira testemunha já teria sido ouvida, em rede nacional, bem antes do início do julgamento. Dessa forma, quem formaria o corpo de jurados, para o julgamento do caso, já começaria a formar seu convencimento antes de ter acesso as provas oficiais colhidas nos autos e apresentadas sob o âmbito do contraditório judicial.

As provas, portanto, passam a ser apresentadas pela mídia e não dentro de um devido processo legal. Isso acaba, por muitas vezes, permitindo que o conselho de sentença tenha acesso a provas que nem sempre são legais/lícitas e que venham a interferir, de forma significativa, no julgamento do caso. Em contrapartida, em julgamentos que não são repercutidos pela imprensa, o conselho de sentença só teria acesso as provas lícitas e os fatos seriam apresentados pelas partes, tudo conforme o devido processo legal.

Em 2012, após longas investigações, iniciou-se o julgamento de Bruno, Luiz Henrique Romão, Marcos Aparecido dos Santos, Dayanne Rodrigues, Fernanda Gomes, Elenilson Vitor e Wemerson Marques de Souza.

Ocorre que, mesmo após 2 anos do desaparecimento da vítima e de longas investigações, inclusive de enormes campanhas de mídia para que o caso fosse investigado e seus responsáveis punidos, o corpo dela nunca foi encontrado. Fato este que foi, constantemente, abordado pelos advogados de defesa de Bruno. 
O fato de não terem encontrado o corpo da vítima e de não existirem provas concretas de que a teriam matado, por si só, dentro do regular processo penal e respeitadas as garantias processuais, impediria a condenação dos investigados, tendo em vista o princípio da presunção de inocência, no qual a dúvida deverá pesar, sempre, a favor do réu.

Apesar disso, a justiça reconheceu que ela teria sido estrangulada e, após, esquartejada, condenando o acusado, Bruno, pela morte e ocultação de cadáver, a uma pena de vinte e dois anos e três meses de prisão por sua participação no sequestro e assassinato de Eliza Samúdio.

Importante ressaltar que, o julgamento de Bruno pode ser acompanhado a todo o tempo pelo site do G1, uma vez que a própria juíza do caso, Marixa Fabiana, estabeleceu que nenhum lugar na plateia seria oportunizado para populares da região, sendo utilizados apenas pelos parentes da vítima, jornalistas e estudantes de direito. Dessa forma, a todo o momento, vimos a população pedindo justiça e, para isso, pediam que Bruno e os outros acusados fossem condenados.

Vejam que o corpo de Eliza não foi encontrado, não haviam provas robustas de que teria sido Bruno mandante do assassinato da modelo e, mesmo assim, ele foi condenado. Percebemos, portanto, que Bruno sentou-se no "banco dos réus" já na qualidade de condenado, uma vez que a mídia já havia formado o convencimento da população muito antes do julgamento oficial do caso.

Em entrevista dada a revista veja, o advogado de Bruno se queixa: 
A imprensa condenou um homem inocente. Em uma sociedade televisionada como a nossa, apresentadores 'são formadores de opinião e produzem vereditos antes da culpa ser formada'.” (...) Ah, ele foi condenado por causa da mídia, não tem dúvida. Não há provas, não há cadáver. (...) Dizem que ela foi estrangulada, mas não há vestígios, e que depois ela foi picada e os cachorros comeram, mas não há tártaro da Eliza Samudio nos cães. (...) Eles fizeram perícia no local onde era o canil e não há material genético da moça. Assim, a estória e não história, pois falo de fábula, não foi ratificada pela prova técnica. ${ }^{45}$

Dessa forma, o princípio da presunção de inocência, tão caro a nossa Constituição, fica mitigado diante da influência opressiva da mídia nos casos de grande repercussão como foi o do goleiro Bruno Fernandes. Questiona-se, portanto, quais seriam as saídas, em se tratando de crimes julgados pelo Tribunal do Júri, para evitar tamanha influência opressiva.

Posto isto, veremos, no último capítulo deste trabalho, as possíveis soluções capazes de minimizar a influência da mídia nos julgamentos criminais.

\subsubsection{A Operação Lava-Jato e o Vazamento Dos Áudios Entre Luís Inácio Lula Da Silva e a ex-Presidente Dilma Rousseff}

Salienta-se, desde o princípio, que não cabe no presente trabalho fazer uma análise completa da "Operação Lava-jato" pois, para isso, seria necessário um trabalho inteiro visando discutir todos os acontecimentos ocorridos. Tratarse-á aqui apenas de um episódio, ocorrido dentro desta operação, que demonstra, claramente, a influência dos meios de comunicação no processo criminal.

45 TEIXEIRA, Paulo Victor. "Foi condenado por causa da mídia", dispara ex-advogado do goleiro Bruno. Disponível em < http://www.olhardireto.com.br/juridico/noticias/exibir.asp?id=35917\&noticia=foi-condenado-porcausa-da-midia-dispara-ex-advogado-do-goleiro-bruno-veja-entrevista-exclusiva- >. Acesso em 15 de maio de 2018. 
O episódio diz respeito ao levantamento do sigilo de um pequeno diálogo por meio telefônico entre Dilma Rousseff, à época presidente da república em exercício do mandato e Luís Inácio Lula da Silva, seu antecessor na função, sobre a nomeação deste ao cargo de Ministro da Casa Civil.

O que causa surpresa no episódio narrado não é, apenas, o fato da incompetência do juiz de primeiro grau da $13^{\mathrm{a}}$ Vara Federal da Comarca de Curitiba, juiz Sérgio Moro, em ter levantado o sigilo de uma interceptação telefônica que envolvia agente com prerrogativa de foro, mas sim que a providência tomada, por esse, tenha sido pouco tempo depois da captação do áudio da conversa e disponibilizada a imprensa - sem que tal providência tivesse qualquer finalidade útil para investigação criminal aparentemente.

Ora, a divulgação da conversa pelos meios de comunicação se deu quase que instantaneamente. Não somente, a mídia no presente episódio fez verdadeira campanha contra eventual nomeação, transformando Dilma Rousseff e "Lula" em verdadeiros comparsas criminosos que tentavam se furtar das acusações e do julgamento criminal deste último, pelo juiz considerado e exaltado, por esta mesma mídia, como o "super-homem" - o mito do protetor que a tudo enfrenta para, sem limites de autossacrifício, realizar a justiça - que colocaria fim a corrupção e impunidade no Brasil. ${ }^{46}$

Portanto, percebe-se, claramente, o quanto a justiça e a mídia caminham juntas como se estabelecessem verdadeiras parcerias em prol do interesse do respeitável público e, também, como a influência opressiva da mídia consegue ditar os caminhos que a justiça tomará em suas decisões.

46 GOMES, Marcus Alan de Melo. Crítica à cobertura midiática da operação Lava-jato. Disponível em 
Marcus Alan, assim afirma, vejamos:

A consequência mais nefasta dessa associação é o que Bourdieu chama de 'uma verdadeira transferência do poder de julgar', efeito que, no âmbito da Operação Lava Jato, se percebe pela forma como as decisões proferidas pelo juiz da 13. ${ }^{a}$ Vara Criminal Federal de Curitiba satisfazem as expectativas punitivas alimentadas pela repercussão midiática da investigação. A usurpação da função judicial pela imprensa e a mudança indevida do locus do julgamento encontraram eco na própria atividade jurisdicional, em um consórcio harmônico em que u conta com o apoio do outro para justificar suas escolhas e ações. $^{47}$

Sendo certo que, após tal episódio, o Supremo Tribunal Federal impediu a nomeação de Luís Inácio Lula da Silva.

Dessa forma, o Poder Judiciário ao ceder aos clamores da opinião pública(da) e agir diante de um suposto interesse público ignora o sentido e o alcance das regras de tutela da privacidade e intimidade - "em matéria processual penal: precisamente proteger do conhecimento público aquilo que diz respeito ao âmbito restrito do privado e que não tem valor para a investigação policial ou instrução criminal". ${ }^{48}$

A influência midiática, portanto, é tamanha no caso da Operação LavaJato que a caracterização e mistificação dos personagens envolvidos neste verdadeiro "reality show policial" se materializou com a representação do expresidente da república, Luís Inácio Lula da Silva, por um boneco plástico inflável em trajes de presidiário que foi divulgada em quase todas as notícias relacionadas à investigação. ${ }^{49}$ 
Representação esta que demonstra, claramente, o prejuízo ao princípio da presunção de inocência diante das enormes campanhas de publicidade opressiva que envolve a Operação Lava-jato e que envolveu o episódio narrado.

\subsubsection{A Influência Opressiva Midiática E A Condenação Automática Do Réu}

Através dos casos abordados podemos perceber como o princípio da presunção de inocência sofre interferências da publicidade opressiva em se tratando de julgamentos criminais que são conduzidos pelos grandes meios de comunicação.

É claro que, não se está defendendo aqui que não haja veiculação dos casos criminais pela mídia, pois como já se tratou neste trabalho, a liberdade de informação, expressão e de imprensa é, também, um direito constitucional e que, por isso, deve ser garantido, igualmente, como o da presunção de inocência, do devido processo legal, etc.

Entretanto, a forma utilizada, muitas vezes, por essa imprensa para retratar a investigação criminal, os fatos e pessoas envolvidas no evento criminoso viola o direito do acusado em ser considerado presumidamente inocente.

Simone Schreiber (2008), afirma que: 
É importante desmistificar o papel que a imprensa se atribui na democracia de instituição descompromissada e imbuída dos melhores propósitos, legítima tradutora dos interesses da sociedade e fiscalizadora dos órgãos do Estado, comprometida unicamente com a busca imparcial da verdade. ${ }^{50}$

A exposição, muitas vezes, com uma abordagem sensacionalista feita pela mídia sobre os fatos criminosos é marcada por chocar o público, causar impacto, envolvendo-o emocionalmente aos fatos apresentados nem que para isso ela precise relativizar as garantias individuais dos supostos autores do crime. Importante destacar que o acusado, que não está ainda condenado, é um sujeito de direito e como tal deve ser tratado pela mídia.

Em verdade, no mundo globalizado no qual vivemos, os meios de comunicação são os principais responsáveis pela criação no imaginário coletivo da sensação de impunidade, de medo e de insegurança coletiva. Segundo Eugenio Raul Zaffaroni, em seu artigo delinquência urbana e vitimização da vítima, é a mídia que constrói a realidade da delinquência urbana. ${ }^{51}$

Cobram, assim, respostas cada vez mais rápidas das autoridades de persecução penal nem que para isso seja necessário relativizar ou retirar garantias individuais constitucionalmente garantidas, em um verdadeiro sistema de "doa a quem doer".

Assim merece razão René Dotti ao afirmar que, uma das dez pragas do sistema penal são os "juízes paralelos: determinados profissionais da mídia

50 SCHREIBER, Simone. A publicidade opressiva de julgamentos criminais - Rio de Janeiro: Renovar, 2008. pág. 210.

51 ZAFFARONI, Eugênio Raul. Delinquência urbana e vitimização da vítima. 2010, p. 39 Apud. ROCHA, Rebeca; FERNANDES, Amanda. A vitimização e a condenação prévia no plano midiático. Disponível em < file:///C:/Users/Asus/Downloads/7197-18453-1-PB.pdf > Acesso em 19 de abril de 2018. 
eletrônica e muitos juristas de plantão (...) apóstolos da suspeita temerária e militantes da presunção da culpa. ",52

Dessa forma, a justiça criminal ao atender aos desejos punitivos desses “juízes paralelos” acaba, por vezes, transformando o direito penal mínimo em máximo. Assim, cria-se "um modelo de Estado mínimo na afirmação de direitos e máximo no controle penal, e por uma imprensa inserida nas engrenagens das grandes corporações comunicacionais, que não mais fiscalizam o poder, pois também o exercem. "53

O sistema penal, por sua vez, acaba funcionando como se fosse um verdadeiro "fast food" - alimentando a coletividade de respostas rápidas, padronizadas, imprecisas e, por inúmeras vezes, de baixa qualidade.

Portanto, quando a mídia decide acompanhar um caso criminal e repercuti-lo para sociedade, realizando publicidade opressiva em cima do caso e, principalmente, do acusado, efetiva-se uma punição anterior ao juízo de culpabilidade - com base apenas na acusação, momento no qual o indivíduo ainda deveria estar sob a proteção do princípio constitucional da presunção de inocência, tornando a condenação, desse, automática e dificultando a obtenção de um resultado diferente do já manifestado pela mídia.

Assim, também, já afirmava Nilo Batista, vejamos:

52 DOTTI, René. As dez pragas do sistema penal brasileiro, em James Tubenchlak (org.) Doutrina, Rio de Janeiro, ID, 2001, v.11, p.288 Apud. BATISTA, Nilo. Mídia e sistema penal no capitalismo tardio. Disponível em <http://www.bocc.ubi.pt/pag/batista-nilo-midia-sistemapenal.pdf> Acesso em 19 de abril

53 GOMES, Marcus Alan de Melo. Crítica à cobertura midiática da operação Lava-jato. Disponível em $<$ http://www.mpsp.mp.br/portal/page/portal/documentacao_e_divulgacao/doc_biblioteca/bibli_servi cos_produtos/bibli_boletim/bibli_bol_2006/122.09.PDF >. Acesso em 18 de abril de 2018. 
Quando o jornalismo deixa de ser uma narrativa com pretensão de fidedignidade sobre a investigação de um crime ou sobre um processo em curso, e assume diretamente a função investigatória ou promove uma reconstrução dramatizada do caso - de alcance e repercussão fantasticamente superiores à reconstrução processual - passou a atuar politicamente. ${ }^{54}$

Sendo assim, percebemos que, estamos fora do contexto convencional do "trial by media", não se tratando de influenciar apenas um tribunal, senão de realizar o próprio julgamento. ${ }^{55}$

Os casos abordados, no presente trabalho, são casos em que a mídia foi tão exaustiva na repercussão que, acabou ocasionando verdadeiros prejuízos as garantias constitucionais dos acusados. Percebemos, em ambos os casos, que apenas houve a confirmação judicial da condenação que já era manifestada pela mídia durante o acompanhamento dos casos.

Em se tratando de crimes de competência do Tribunal do Júri a influência opressiva da mídia ainda se torna mais relevante diante da dinâmica deste procedimento, uma vez que o acusado não é julgado por um juiz ou por juízes togados, mas sim por juízes leigos que nem sempre conhecem as garantias processuais envolvidas em um processo criminal. Esse tema, por sua vez, será objeto de um subcapítulo específico.

54 BATISTA, Nilo. Mídia e sistema penal no capitalismo tardio. Disponível em <http://www.bocc.ubi.pt/pag/batista-nilo-midia-sistema-penal.pdf $>$ Acesso em 19 de abril ${ }^{55}$ Ibid. 
É necessário pensarmos, portanto, se a atuação da mídia que temos hoje - e aqui não falo do papel funcional da mídia em informar a coletividade de forma desinteressada, buscando sempre um trabalho compromissado com a verdade, mas sim de uma mídia que oprime e massacra a imagem e as garantias do acusado condenando-o muito antes de um julgamento justo - é compatível com um Sistema Penal que tem como princípio basilar a presunção de inocência. ${ }^{56}$

\subsection{O Tribunal do Júri}

Em diversas constituições do Brasil o Tribunal do Júri esteve presente. $\mathrm{Na}$ constituição atual, de 1988, este vem disposto dentro das garantias e direitos fundamentais sendo, inclusive, considerado cláusula pétrea, o que impede qualquer tentativa de suprimir o instituto.

O Tribunal do Júri é, principalmente, uma garantia fundamental, uma vez que tem por objetivo proteger o direito à liberdade, ainda que não diretamente. Dessa forma, em segundo plano seria um direito, existindo na ordem jurídica e sendo legalmente reconhecido, ainda que não venha a ser exercido permitindo, ainda assim, a participação dos cidadãos na realização da justiça.

Em se tratando de um instituto capaz de promover a efetivação da democracia, também, foram estabelecidas garantias específicas ao Tribunal do Júri, previstas no artigo $5^{\circ}$, inciso XXXVIII. Tal artigo assegura: a plenitude de defesa, o sigilo das votações, a soberania dos veredictos, e a competência para o julgamento dos crimes dolosos contra a vida.

56 SCHREIBER, Simone. A publicidade opressiva de julgamentos criminais - Rio de Janeiro: Renovar, 2008. pág. 211. 
O código de processo penal, também, disciplina o Tribunal do Júri em seus artigos 406 a 497.

O procedimento do Júri, por sua vez, é bifásico, ou seja, dividido em duas fases, uma primeira de instrução preliminar - fase compreendida entre o recebimento da denúncia e a decisão de pronúncia (irrecorrível) e uma segunda fase no julgamento em plenário - inicia-se com a confirmação da pronúncia e vai até a decisão proferida no julgamento realizado no plenário do Tribunal do Júri pelos jurados (juízes leigos). ${ }^{57}$

Dessa forma, percebemos que o Tribunal do Júri é um instituto de extrema importância na efetivação da democracia participativa, entretanto, por ser um instituto composto por cidadãos comuns, juízes leigos que julgam seus semelhantes, os casos levados ao Tribunal do Júri sofrem de maneira mais incisiva e mais prejudicial pela influência opressiva da mídia.

Por isso, existem no próprio procedimento formas de tornar o julgamento mais imparcial e desvinculado possível dessa influência midiática, ainda que nem sempre, como vimos e veremos, isso seja eficaz. Essa questão será tratada mais detalhadamente nos próximos tópicos a serem abordados no trabalho.

57 LOPES JR., Aury. Direito processual penal. - 12. ed. - São Paulo: Saraiva, 2015. pág. 784. 


\subsubsection{Do Sigilo Das Votações}

O sigilo das votações é uma medida constitucionalmente prevista no artigo $5^{\circ}$, inciso XXXVIII, alínea 'b', que busca garantir a imparcialidade do julgamento.

Isso ocorre, uma vez que é por meio do sigilo das votações (forma de computar os votos dos jurados, como também, de o fazer em uma sala secreta) que se garante que os jurados ao votarem possam fazê-lo sem qualquer pressão externa, seja por parte dos familiares da vítima ou de parentes e amigos do réu, seja, inclusive, pela presença ostensiva da mídia. Assim, o jurado que representa, naquele julgamento, a vontade soberana do povo pode decidir de forma livre e sempre mantendo o compromisso de se apoiar nas provas dos autos, assim como, no que foi sustentado em plenário qual será o destino da causa julgada.

Dessa forma, o sigilo das votações torna-se uma importante medida no combate da influência opressiva da mídia nos julgamentos, uma vez que com isso, o jurado não se sentirá envergonhado ou com medo de decidir de acordo com a sua convicção, tendo em vista que ninguém saberá qual foi sua decisão, podendo-a fazer da forma mais livre possível.

Ocorre que, ao mesmo tempo em que o sigilo é importante para proteger os jurados de eventuais intimidações, este não permite que se analisem possíveis prejuízos marcados pela influência negativa da mídia sobre o caso, uma vez que não se expõe os motivos pelos quais os jurados estão decidindo daquela forma, decidem, esses, por sua íntima convicção. 
Importante ressaltar que, não é objeto do presente trabalho questionar a validade do Tribunal do Júri, democraticamente, previsto em nossa Constituição Cidadã.

\subsubsection{Da Incomunicabilidade dos Jurados}

A incomunicabilidade dos Jurados está presente no artigo $466, \S 1^{\circ}$ do Código de Processo Penal, que prevê:

O juiz presidente também advertirá os jurados de que, uma vez sorteados, não poderão comunicar-se entre si e com outrem, nem manifestar sua opinião sobre o processo, sob pena de exclusão do Conselho e multa, na forma do $\$ 2^{\circ}$ do art. 436 deste Código. ${ }^{58}$

A regra disposta neste artigo garante, por assim dizer, a disposta na Constituição, no que diz respeito ao sigilo, pois impede que os jurados após formado o conselho de sentença venham a externar suas opiniões fazendo com que estas possam influenciar outros jurados e, ao final, o veredicto.

Guilherme de Souza Nucci, assim entende:

A incomunicabilidade dos jurados significa que os jurados não podem conversar entre si, durante os trabalhos, nem nos intervalos, a respeito de qualquer aspecto da causa posta em julgamento, especialmente deixando transparecer a sua opinião. Logicamente, sobre os fatos desvinculados do feito podem os jurados conversar, desde que não seja durante a sessão - e sim nos intervalos -, pois não se quer a mudez dos juízes leigos e sim a preservação da sua íntima convicção (...) Deve formar seu convencimento sozinho, através da captação das provas apresentadas, valorando-as segundo seu entendimento. Portanto, cabe ao juiz-presidente impedir a manifestação da opinião do jurado sobre o processo, sob pena de nulidade da sessão de julgamento."59

58 Código Processo Penal, 1941. Disponível em: < http://www.planalto.gov.br/ccivil_03/decretolei/Del3689Compilado.htm> Acesso em 02 jun. 2018.

59 NUCCI, Guilherme de Souza. Código de processo penal comentado. 10. ed. rev., atual. E ampl. São Paulo: Editora Revista dos Tribunais, 2011. 
Além da impossibilidade de comunicação entre os jurados é importante ressaltar que, durante a sessão de julgamento até o seu término, esses ficarão sem acesso a qualquer outro meio externo, ou seja, não poderão se utilizar de celulares, internet, se comunicar com parentes e amigos, ter acesso às notícias/jornais, que possam, de qualquer forma, influenciar as convicções deles durante o julgamento.

Portanto, podemos perceber que a incomunicabilidade dos jurados é uma importante medida no que diz respeito a busca de um julgamento mais imparcial, já que cada jurado decidirá de acordo com a sua consciência e com as provas trazidas aos autos do processo.

Entretanto, essa medida no que diz respeito a julgamentos com grande repercussão midiática e visibilidade não impede que os jurados, diante das campanhas de mídia propagadas no caso criminal em julgamento, tenham formado suas convicções anteriormente, o que tornaria a incomunicabilidade apenas um ato formal, sem qualquer efetividade concreta.

Assim, também, entende Ana Lúcia Menezes Vieira, vejamos:

O objetivo da incomunicabilidade, ou seja, assegurar a independência e imparcialidade dos jurados, já sofre interferência anterior à existência formal do ato que se verifica com o compromisso dos juízes de fato. Como cidadãos, os jurados, provocados pelos debates de mídia, já externaram suas posições, já manifestaram suas opiniões sobre os fatos relacionados com o processo, já foram influenciados pela opinião de terceiros, por meio de jornais, revistas, televisão, quando já não formaram suas convicções. Daí entendermos que a incomunicabilidade não resguarda, senão formalmente, a imparcialidade dos jurados. ${ }^{60}$

60 VIEIRA, Ana Lúcia Menezes. Processo Penal e mídia. São Paulo: Editora Revista dos Tribunais, 2003, p.249. Apud. SCHREIBER, Simone. A publicidade opressiva de julgamentos criminais -

Rio de Janeiro: Renovar, 2008. pág. 232. 


\subsubsection{Do desaforamento}

O artigo $427^{61}$ do Código de Processo Penal traz como medida de urgência a figura do desaforamento. Assim é porque, o desaforamento implica na mudança de competência em razão do lugar do cometimento do crime trazida no artigo $6^{0}{ }^{62}$ do Código Penal. Além disso, também implica que o réu não seja julgado pelo juiz naturalmente competente para decidir a demanda, o que também incorreria na inobservância do princípio do juiz natural trazido na Constituição Federal de 1988, art. $5^{\circ}$, inciso LIII.

Segundo Aury Lopes Jr. (2015), o desaforamento é o procedimento no qual:

(...) o processo é (des)aforado, ou seja, retirado do seu foro, daquela comarca originariamente competente para julgá-lo, e encaminhado para julgamento em outro foro (comarca ou circunscrição judiciária, caso seja da competência da Justiça Federal). ${ }^{63}$

61 Art. 427. Se o interesse da ordem pública o reclamar ou houver dúvida sobre a imparcialidade do júri ou a segurança pessoal do acusado, o Tribunal, a requerimento do Ministério Público, do assistente, do querelante ou do acusado ou mediante representação do juiz competente, poderá determinar o desaforamento do julgamento para outra comarca da mesma região, onde não existam aqueles motivos, preferindo-se as mais próximas. (Redação dada pela Lei no 11.689 , de 2008)

$\S 10 \mathrm{O}$ pedido de desaforamento será distribuído imediatamente e terá preferência de julgamento na Câmara ou Turma competente. (Incluído pela Lei no 11.689, de 2008)

$\S 20$ Sendo relevantes os motivos alegados, o relator poderá determinar, fundamentadamente, a suspensão do julgamento pelo júri. (Incluído pela Lei nº 11.689, de 2008)

§ 3oSerá ouvido o juiz presidente, quando a medida não tiver sido por ele solicitada. (Incluído pela Lei ${ }^{\circ} 11.689$, de 2008)

$\S 4$ 4oNa pendência de recurso contra a decisão de pronúncia ou quando efetivado o julgamento, não se admitirá o pedido de desaforamento, salvo, nesta última hipótese, quanto a fato ocorrido durante ou após a realização de julgamento anulado. (Incluído pela Lei $\mathrm{n}^{\circ} 11.689$, de 2008)

62 Art. $6^{\circ}$-Considera-se praticado o crime no lugar em que ocorreu a ação ou omissão, no todo ou em parte, bem como onde se produziu ou deveria produzir-se o resultado (Redação dada pela Lei $\mathrm{n}^{\circ}$ 7.209, de 1984)

63 LOPES JR., Aury. Direito processual penal. - 12. ed. - São Paulo: Saraiva, 2015. pág. 811. 
São quatro hipóteses em que seria possível a admissão do desaforamento, quais sejam: (1) Interesse da Ordem Pública; (2) Dúvida sobre a imparcialidade do júri; (3) A segurança do réu exigir; (4) Comprovado excesso de serviço. ${ }^{64}$

(1) No que diz respeito ao interesse da ordem pública, a doutrina entende que esta funcionaria como uma cláusula guarda-chuva, pois nessa hipótese poderiam estar presentes inúmeros motivos para a admissão do desaforamento como, por exemplo, questões de comoção social até impossibilidade temporária por obras ou por qualquer outro motivo ocorridas no foro.

(2) Quanto a dúvida sobre imparcialidade do júri, trata-se de uma causa mais delicada e mais difícil de ser comprovada o que gera, muitas vezes, a sua inadmissão. Isso decorre do fato de que a afirmação de quebra de imparcialidade de um grupo de pessoas, no caso dos jurados, encontra maior dificuldade de ser comprovada.

Normalmente pedidos de desaforamento com base nesse fundamento encontram respaldo em razão da influência opressiva da mídia diante de alguns casos criminais. Isso porque, em determinados casos, as campanhas midiáticas são tão grandes que difícil seria que os jurados (conselho de sentença) conseguissem julgar a causa com a mesma imparcialidade, independência e distanciamento esperados.

Aury Lopes jr. (2015), nessa mesma linha, afirma que:

64 Ibid. pág. 812-813. 
O bizarro espetáculo midiático e a publicidade abusiva em torno de casos graves ou que envolva pessoas influentes ou personalidades públicas fazem com que exista fundado receio de que o eventual conselho de sentença formado não tenha condições de julgar o caso penal com suficiente tranquilidade, independência e estranhamento $(\ldots){ }^{65}$

Ocorre que, por se tratar de questão probatória fática, dificilmente a defesa do réu consegue provar essa prejudicialidade e, portanto, raramente o desaforamento é admitido pelos Tribunais.

Além disso, é necessário que se faça, ainda dentro dessa motivação, uma análise quanto ao sentimento gerado em relação ao acusado, uma vez que é normal que os jurados tenham aversão ao crime praticado, entretanto, o que não poderá ocorrer é a demonstração de uma vontade/ânimo anormal em julgar o réu. Caso essa hipótese ocorra, é necessário desaforar o processo.

(3) O motivo que diz respeito a segurança do réu se estabelece em razão da possibilidade do acusado ser linchado ou ocorrerem fatores que ponham em risco a segurança e vida dele.

(4) O último motivo é em virtude de comprovado excesso de serviço, e se justifica diante das garantias que circundam o processo, quanto ao julgamento ser realizado em prazo razoável. Garantia esta, inclusive, prevista na Constituição em seu artigo $5^{\circ}$, inciso LXXVIII.

65 Ibid. pág. 812. 
Vemos, portanto, que o desaforamento apesar de constar como uma medida que seria capaz de minimizar os efeitos da influência midiática nos julgamentos criminais no Tribunal do Júri é ainda uma questão muito sensível aos olhos dos Tribunais, uma vez que para sua admissão é necessário a relativização de garantias constitucionais e processuais, igualmente, importantes.

Dessa forma, em casos que seria necessário a utilização e aceitação da medida para se alcançar um julgamento mais imparcial, ela não ocorre. Portanto, mais uma vez, questiona-se a capacidade de satisfação das medidas capazes de oferecer ao réu um julgamento justo.

Não somente, o desaforamento em casos de julgamentos com repercussão nacional não possui grande efetividade, uma vez que já serão julgados em grandes centros e por terem sido objeto de notícias nacionais faz com que a medida não impeça ou amenize a parcialidade dos jurados na decisão do julgamento.

Dessa forma, seriam necessárias medidas mais eficazes quando se tratasse de casos que são acompanhados e divulgados maciçamente pelos grandes veículos de comunicação que dão seu veredicto antes mesmo do caso ser submetido judicialmente à análise, realizando um verdadeiro "trial by media". 66

66 Frase popular no final do século 20 e início do século 21 para descrever o impacto da cobertura televisiva e jornalística sobre a reputação de uma pessoa ao criar uma percepção generalizada de culpa ou inocência antes ou depois de um veredicto em um tribunal. Disponível em < https://en.wikipedia.org/wiki/Trial_by_media >. Acesso em 23 de maio de 2018. 


\subsection{A publicidade das decisões na Constituição de 1988.}

A publicidade está prevista na Constituição em seus artigos $5^{\circ}$, inciso LX, 93, inciso IX e, também, no 37.

Ela tem especial acento na efetivação da democracia, uma vez que é por meio dela que o povo passa a entender e controlar a atuação de seus representantes, já que a própria constituição dispõe em seu artigo $1^{\circ}$, parágrafo único, que: "todo poder emana do povo, que o exerce por meio de seus representantes eleitos ou diretamente, nos termos desta Constituição. "

Entretanto, o poder judiciário não é composto por representantes eleitos pelo povo, o que faz com que o princípio da publicidade dê às atuações daquele, legitimidade. Dessa forma, ao tornar pública as decisões, o Poder Judiciário se legitima dentro de uma sociedade democrática que preza pela transparência de seus atos.

No âmbito do processo penal, o princípio da publicidade vai além do controle dos atos pelos representantes eleitos ou do poder judiciário, uma vez que garante ao réu que este possa exercer sua defesa de uma forma ampla, restringindo-se ao máximo os atos que poderão correr em segredo de justiça ou em sigilo (artigo $5^{\circ}$, inciso XXXIII e LX; artigo 93, inciso IX da Constituição Federal de 1988). Portanto, a publicidade no processo penal, ao final, também tem o objetivo de garantir um julgamento justo. 
A publicidade tem um aspecto amplo e não apenas ligado ao processo em si, ou seja, permite que o público também tenha acesso aos atos do processo criminal. Esse fato não deixa de ser, também, uma garantia do acusado, tendo em vista que haveria uma maior fiscalização da população, o que evitaria atos arbitrários praticados pelo Estado.

Se entendermos como uma garantia do acusado, sendo este o titular desse direito, ele poderia dispor unilateralmente a ela, pleiteando-se o sigilo, para se reservar da exposição, da humilhação e até da influência opressiva da mídia. ${ }^{67}$

Inclusive, observando-se a jurisprudência norte-americana, poderiam ser adotadas, no Brasil, as chamadas gag orders, ou seja, a imposição de sigilo absoluto pelo juiz sobre o processo, impedindo que tanto a defesa, quanto a acusação prestem informações a quem quer que seja sobre o caso em julgamento. Tal medida não constituiria censura, pois é prevista constitucionalmente. ${ }^{68}$

Ocorre que, como vimos, a publicidade na Constituição possui dupla função, ou seja, é uma garantia do acusado, mas também é uma forma de controle dos atos do poder judiciário e, sendo assim, como as garantias do acusado são importantes, o direito coletivo de informação também tem especial relevância na Constituição como já observado no capítulo dois deste trabalho.

67 SCHREIBER, Simone. A publicidade opressiva de julgamentos criminais - Rio de Janeiro: Renovar, 2008. pág. 247.

68 FREITAS, Paulo Henrique. Julgamentos midiáticos: O princípio da publicidade e o direito a um julgamento justo (fair trial). Disponível em < https://jus.com.br/artigos/58643/julgamentosmidiaticos-o-principio-da-publicidade-e-o-direito-a-um-julgamento-justo-fair-trial/4 >. Acesso em 24 de maio de 2018. 
Não somente, a publicidade não é absoluta no processo e, portanto, poderá sofrer restrição, entretanto, a própria constituição prevê os valores constitucionais que justificariam essa medida, como nos casos de violação da intimidade, em razão do interesse social ou quando houver colisão entre direitos fundamentais.

Portanto, a restrição a publicidade pode ser vista como uma das formas de evitar a influência opressiva midiática garantindo, assim, um julgamento mais justo e imparcial. 


\section{Capítulo 4. Colisão De Direitos Fundamentais: Presunção De Inocência E Julgamento Criminal Justo Versus Liberdade De Expressão E De Imprensa}

\subsection{A Diferenciação Entre Regras E Princípios E A Aplicação Das Técnicas De Ponderação.}

Antes de abordarmos critérios para a aplicação das técnicas de ponderação necessárias para a resolução dos conflitos apresentados é necessário fazer uma pequena diferenciação entre as regras e os princípios.

Existem dois grandes grupos que diferenciam as regras dos princípios; o primeiro que entende as diferenças entre regras e princípios como fracas e o segundo que entende como fortes.

O primeiro grupo entende que os princípios seriam normas de enorme abstração, generalidade e que possuiriam fundamentos basilares, pelos quais todas as normas deveriam ser interpretadas e aplicadas. As regras, por sua vez, seriam dotadas de pouca abstração e generalidade e nenhuma ou pouca subjetividade em sua aplicação. Dessa forma, percebe-se que o primeiro grupo faz uma diferenciação gradual entre as regras e princípios e não estrutural.

O segundo grupo, por sua vez, afirma que a distinção não se dá no grau de abstração, generalidade ou relevância da norma para o Ordenamento Jurídico, mas sim da forma que elas são aplicadas, senão vejamos: 
O fundamento dessa distinção está na estrutura normativa: os princípios, porque instituem mandamentos superáveis no confronto com outros princípios, permitem o sopesamento, ao passo que as regras, porque estabelecem deveres pretensamente definitivos, eliminam ou diminuem sensivelmente a liberdade apreciativa do aplicador. ${ }^{69}$

Portanto, percebemos que há uma distinção forte entre os princípios e as regras, ou seja, enquanto o primeiro estabelece deveres provisórios e são aplicados por meio de ponderação (sopesamento concreto entre razões colidentes), a segunda institui deveres definitivos que são aplicados por meio da subsunção (encaixe entre o conceito veiculado pela norma e o fato concreto).

Humberto Ávila, em seus estudos, propõe uma metodologia para distinguir regras e princípios observando-se as diferenças estruturais para a aplicação de cada uma das normas estudadas.

Sustenta assim que, as regras descrevem diretamente os comportamentos impostos e indiretamente os fins visados. Com isso, para sua aplicação quase não dependem da interpretação de outras normas, entretanto, para que esta não seja aplicada, demanda do aplicador um esforço maior sobre as razões do afastamento do comportamento descrito e exigido na regra. ${ }^{70}$

Os princípios, por sua vez, se diferem das regras, justamente, por não estabelecerem diretamente os comportamentos devidos, mas apenas os fins visados. Devendo, assim, serem adotados os comportamentos devidos a fim de realizar "a busca ou a preservação de um estado ideal de coisas" estabelecido na norma. O aplicador, por sua vez, deverá "argumentar de modo a fundamentar uma avaliação de correlação entre os efeitos da conduta a ser adotada e a realização gradual do estado de coisas exigido."

69 ÁVILA, Humberto. Princípios e regras e a segurança jurídica. Revista de Direito do Estado, nº1. Rio de Janeiro: Renovar, 2006, p.192.

70 Ibid. pág. 65-66. 
Não somente, os princípios são complementares e parciais, já que compreendem apenas partes de aspectos importantes para a tomada de decisão não tendo a pretensão de gerar uma solução específica, mas de contribuir ao lado de outros motivos para a tomada de decisão. Sendo certo que, sua interpretação é dependente do exame problemático. ${ }^{71}$

Os autores que entendem existir uma diferenciação forte entre regras e princípios, como o autor estudado no presente trabalho, ligam esta distinção a técnica de ponderação na resolução de conflitos. Ávila afirma que, a ponderação deveria ser definida como um postulado normativo aplicativo, uma vez que se trataria de normas que auxiliam na aplicação de outras normas.

A ponderação utilizada como técnica para a resolução de conflitos importa na identificação, por parte do aplicador, se sobre o caso concreto incide princípios distintos, após, no sopesamento destes com o caso específico e, ao final, na declaração da prevalência de um ou mais princípios sobre os outros.

Importante salientar que, essa prevalência se dará no caso concreto não importando em prevalência absoluta, já que caso os mesmos princípios voltem a colidir, outros resultados poderão surgir a partir de uma nova ponderação. Percebemos, assim, que essa técnica requer avaliações de maior caráter subjetivo e dão maiores poderes ao aplicador das normas.

71 ÁVILA, Humberto. Teoria dos princípios. Da definição à aplicação dos princípios jurídicos. São Paulo: Malheiros, 2003, p.66-69. 
Humberto Ávila considera que a ponderação poderá ser utilizada em qualquer conflito que envolva, por exemplo, bens jurídicos, valores e princípios e não apenas aqueles conflitos que envolvam normas.

Para a aplicação dessa técnica o autor, supracitado, relaciona três fases, quais sejam: a preparação (análise completa dos elementos e argumentos que serão objeto do sopesamento), a realização (fundamentação da relação entre os objetos do sopesamento) e a reconstrução (formulação da relação de primazia entre os objetos).

O juiz, portanto, deve solucionar a colisão adotando a técnica de ponderação e sujeitando-se ao postulado da proporcionalidade, ou seja, dentro das soluções possíveis para resolução do conflito, deve escolher medidas que possam realizar o fim desejado (adequação), elegendo sempre a que imponha menos restrições ao direito contraposto (necessidade) e avaliando se essa restrição é necessária para a realização satisfatória do fim almejado (proporcionalidade em sentido estrito). ${ }^{72}$

A breve exposição acerca da diferenciação entre regras e princípios e a técnica de ponderação utilizada para resolver conflitos entre normas no caso concreto são de especial relevância neste trabalho, tendo em vista que aborda a colisão de dois princípios fundamentais dentro da Ordem Constitucional, o direito à liberdade de expressão e informação e o direito a um julgamento criminal justo.

72 SCHREIBER, Simone. A publicidade opressiva de julgamentos criminais - Rio de Janeiro: Renovar, 2008. pág. 385. 
Os próximos tópicos tratarão das formas para identificação da colisão entre a liberdade de expressão e informação e o direito a um julgamento criminal justo e das possíveis soluções compatíveis com o Ordenamento Constitucional para o conflito apresentado.

\subsection{Identificação Do Conflito Entre Liberdade De Expressão/Informação E Direito A Um Julgamento Criminal Justo}

A questão tema deste trabalho de conclusão é assunto discutido por muitos, ainda mais nos dias atuais em que tudo é midiatizado. Não se questiona o fato da cobertura midiática dos atos criminosos ser importante e relevante ao interesse público. Ocorre que, a forma com que os meios de comunicação de massa costumam tratar e reportar ao público essas questões, inúmeras vezes, viola direitos fundamentais das pessoas acusadas por esses atos criminosos.

A necessária distinção entre a informação desinteressada e a publicidade opressiva praticada pela mídia é fator fundamental para estabelecermos critérios de ponderação mais harmoniosos sem dar, portanto, à liberdade de expressão posição necessariamente preferencial diante da colisão com outros direitos fundamentais, igualmente, importantes na Constituição Federal. Dessa forma, entende-se que:

A ideia de que, no estado democrático de direito, a imprensa cumpre função social de esclarecer os cidadãos, reportando-lhes a verdade de forma desinteressada e neutra, esconde o fato de que as empresas de comunicação agem, como não poderia deixar de ser, sob uma lógica empresarial; de que as eleições de pauta envolvem decisões políticas (e não técnicas); e de que a 'verdade' reportada nada mais é do que uma versão dos fatos ocorridos, intermediada pela linha editorial do veículo e pela subjetividade dos jornalistas que redigem a matéria. ${ }^{73}$

73 Ibid. pág. 358 
O ditado popular "a pressa é inimiga da perfeição" nunca fez tanto sentido como no caso das notícias sobre os julgamentos criminais que são veiculadas pelos grandes meios de comunicação. Isso porque, hoje, com um mundo globalizado, as notícias precisam ser produzidas, praticamente, em tempo real, o que inviabiliza qualquer análise mais profunda e precisa sobre os fatos. Dessa forma, como forma de garantir o monopólio da informação, a mass media maximiza a utilização de perfis já criados tornando-se mais fácil a produção de notícia e informação em tempo real.

Portanto, devemos identificar quando os meios de comunicação ao informar e noticiar o crime, os julgamentos criminais $\mathrm{e}$ as pessoas supostamente envolvidas, ao em vez de fazerem realizando sua função precípua, informar de forma imparcial e comprometida com a verdade (como preza o código de ética da profissão $)^{74}$, o fazem de forma opressiva, tomando a posição de verdadeiros órgãos de persecução penal.

Sendo assim, caso ocorra esses três elementos estará verificada a incidência do 'trial by media', são eles: ${ }^{75}$

(1) As notícias sucessivas manifestamente prejudiciais ao réu, com caráter opinativo, que formulam um juízo de valor e de culpabilidade antecipado do réu ou ainda que não sejam claramente prejudiciais, mas que divulguem parcialmente as versões dos fatos e provas obtidas por meio ilícitos.

74 Art. $2^{\circ}$ Como o acesso à informação de relevante interesse público é um direito fundamental, os jornalistas não podem admitir que ele seja impedido por nenhum tipo de interesse, razão por que: I - a divulgação da informação precisa e correta é dever dos meios de comunicação e deve ser cumprida independentemente de sua natureza jurídica - se pública, estatal ou privada - e da linha política de seus proprietários e/ou diretores. II - a produção e a divulgação da informação devem se pautar pela veracidade dos fatos e ter por finalidade o interesse público; Disponível em <http://fenaj.org.br/wp-content/uploads/2014/06/04codigo_de_etica_dos_jornalistas_brasileiros.pdf>. Acesso em 25 de maio de 2018.

75 SCHREIBER, Simone. Op. cit. pág. 374-380 
(2) A potencial interferência das notícias desfavoráveis nas decisões dos juízes togados e leigos, principalmente, esses últimos que não motivam suas decisões.

(3) A atualidade do julgamento capaz de gerar uma influência negativa por parte dos meios de comunicação no julgamento. No Brasil, esse tempo é determinado a partir da instauração do inquérito policial até a sentença definitiva.

Dessa forma, caracterizados esses três elementos, ou seja, a veiculação de notícias sucessivas ou parciais pelos meios de comunicação - realizando verdadeiras campanhas de mídia -, um ambiente hostil permeado de publicidades opressivas ao redor do julgamento e a ocorrência disso em julgamentos que estão em andamento, estará identificado o conflito entre o direito de liberdade de expressão/ informação e o direito a um julgamento criminal justo.

Identificado o conflito se faz necessário abordarmos critérios de ponderação, técnica já estudada neste trabalho, capazes de determinar possíveis soluções para a colisão entre direitos tão importantes para o nosso Ordenamento Jurídico.

\subsection{Fixação De Critérios De Ponderação Para A Resolução Do Conflito Apresentado E Possíveis Soluções Compatíveis Com A Constituição Federal De 1988.}


Detectado o conflito entre os direitos fundamentais abordados torna-se necessário a fixação de critérios para a realização da técnica de ponderação. Embora o presente trabalho apresente esses critérios não há que se falar em fixação de padrões de soluções para todos os casos.

Ana Paula Barcellos, em sua obra, "Ponderação, racionalidade e atividade jurisdicional", propõe parâmetros gerais para aplicação da técnica de ponderação, são eles: regras têm preferências sobre princípios e normas que realizam diretamente direitos fundamentais dos indivíduos têm preferência sobre normas relacionadas apenas indiretamente com os direitos fundamentais. ${ }^{76}$

Tanto a liberdade de expressão e informação, quanto o julgamento criminal justo se consubstanciam em normas-princípios. Apesar disso, relacionam-se com enunciados constitucionais que veiculam regras e que descrevem comportamentos diretos a serem seguidos na busca do fim desejado.

Dessa forma, apesar da liberdade de expressão ser um princípio, ela também inclui regras como a vedação a censura, sigilo das fontes, etc. Assim, também, ocorre com o julgamento criminal justo (proveniente do princípio maior do devido processo legal) e que se intensifica com os princípios derivados deste como, por exemplo, a presunção de inocência.

Portanto, seguindo o primeiro parâmetro geral, proposto pela autora acima estudada, se alguma regra concernente aos princípios for objeto de colisão terá preferência na ponderação o princípio protegido pela regra. Citando o exemplo proposto pela autora Simone Schreiber, vejamos:

76 BARCELLOS, Ana Paula de. Ponderação, racionalidade e atividade jurisdicional. Rio de Janeiro: Renovar, 2005, p. 165 e ss. 
(...) se o conflito envolver veiculação na mídia de provas ilícitas, tal elemento jogará a favor do fair trial justificando no caso a imposição à liberdade de expressão. Ao passo que, se estiver em jogo a regra da preservação do sigilo da fonte, eventual colisão pode ser resolvida a favor da liberdade de expressão. "77

Entretanto, caso não estejam em colisões regras que teriam prevalência sobre os princípios deve-se partir para o segundo parâmetro geral, que determina que as normas que diretamente realizam direitos fundamentais têm preferência, leia-se: o princípio da dignidade da pessoa humana. Portanto, em uma eventual colisão entre liberdade de expressão e informação e o direito a um julgamento criminal justo, este, último, terá preferência sobre o primeiro.

Ressalta-se, aqui, que, não se quer dizer que a liberdade de expressão não esteja ligada ao princípio da dignidade humana, ocorre que, o direito a um julgamento criminal justo, respeitando-se o devido processo legal, realiza mais diretamente a dignidade humana do que o interesse coletivo em obter a informação através do exercício da liberdade de expressão.

Portanto, apesar de o crime ser um tema de bastante relevância ao interesse público, o direito a um julgamento criminal justo não pode ser relativizado, sendo certo que o interesse público poderá ser atendido desde que a veiculação midiática do caso não importe em publicidade opressiva.

77 SCHREIBER, Simone. A publicidade opressiva de julgamentos criminais - Rio de Janeiro: Renovar, 2008. pág. 381-382 
Sendo assim, conforme já abordado, o aplicador do direito deve, através da aplicação da técnica exposta e sujeitando-se ao postulado da proporcionalidade, buscar medidas capazes de promover o fim desejado, quais sejam: (1) assegurar que o réu seja julgado sob as garantias do devido processo legal; (2) impondo a menor restrição possível ao direito de liberdade de expressão; (3) verificando se o grau de restrição ao direito de liberdade se justifica diante da relevância do fim a ser observado, qual seja, o julgamento criminal justo.

Posto isto, e diante do estudo realizado, apresentarei quatro soluções compatíveis com o Ordenamento Constitucional que julgo serem mais efetivas em minimizar a influência da mídia nos julgamentos criminais.

Uma primeira solução seria o dilatamento do julgamento, ou seja, suspender-se-ia o processo em andamento até que se pudesse identificar o fim das campanhas de mídia. Essa medida poderia ser usada tanto nos casos que tramitam perante o Tribunal do Júri, quanto nos que tramitam no procedimento comum, julgados por juízes togados. Apesar de a medida não estar prevista na lei brasileira, poderá ser usada na ponderação pelo juiz, pois não encontra incompatibilidade com o Ordenamento. ${ }^{78}$

Além disso, essa medida não implica em restrição à liberdade de expressão, entretanto, deve-se tomar cuidado, uma vez que a adoção dessa poderia interferir em outros valores constitucionalmente previstos como, por exemplo, a celeridade processual, a duração razoável do processo.

78 Ibid. pág. 388-389 
Não obstante, a medida propugnada, aqui, encontraria dificuldade quanto à suspensão do prazo prescricional e a manutenção da prisão cautelar (nos casos em que o réu se encontra preso provisoriamente). Uma vez que, submeter o réu a isso, é tão prejudicial quanto submetê-lo a um julgamento permeado pela publicidade opressiva veiculada pelos grandes meios de comunicação.

Uma segunda solução que poderá ser adotada é a criminalização de condutas expressivas. $^{79}$

Seria uma imposição de punição posterior que se daria em dois enfoques: o primeiro consistente na proibição de divulgação de informações abusivas ou irresponsáveis do jornalista e o segundo consistiria na proibição de divulgação de informações por parte dos magistrados, promotores e demais autoridades administrativas.

Apesar desta solução encontrar respaldo na Constituição de 1988 e na própria jurisprudência do Supremo Tribunal Federal, seria necessário a atuação legislativa para que se aprovasse lei tipificando, por exemplo, o crime de "publicidade opressiva" e, conjuntamente, a proibição de divulgação de informações sobre o caso em julgamento. Sendo certo que, para isso, é necessária uma análise quanto a constitucionalidade do futuro tipo penal e, também, de uma clareza quanto as condutas tipificadas pela norma incriminadora.

79 ANDRADE, Fábio Martins de. Mídia e Poder Judiciário - A influência dos órgãos de mídia no Processo Penal Brasileiro. Rio de Janeiro: Lumen Juris, 2007, pág. 343-345. 
Ressalta-se aqui que, a própria Corte Europeia, inclusive, já decidiu que a condenação de jornalistas por publicidade opressiva não viola a liberdade de comunicação.

Uma terceira solução possível seria a proibição temporária de veiculação de notícia sobre o julgamento por meio de ordem judicial, ou seja, o juiz criminal determinaria, por liminar, que certo meio de comunicação que normalmente realiza campanha de mídia a favor da condenação do réu. na pendência do julgamento, se abstenha de publicar notícias a respeito do processo até que este termine ou até que seja escolhido o conselho de sentença.

Esta medida, por sua vez, afeta, a cobertura real e divulgação imediata dos fatos e opiniões acerca do crime, ficando sacrificado o interesse coletivo em ter acesso a tais notícias. ${ }^{80}$ Não somente, restringe, e muito, a liberdade de expressão e informação, entretanto, encontra respaldo na Constituição de 1988 haja vista que, a vedação a censura não impede que ordens judiciais pró́bam previamente manifestações lesivas a outros direitos fundamentais.

Uma quarta solução, seria a renúncia ao julgamento pelo Tribunal do Júri, ou seja, em casos em que houvesse verdadeira campanha de mídia capaz de influenciar os jurados e prejudicar a imparcialidade do julgamento, o acusado poderia ter o direito de renunciar o julgamento feito pelo Tribunal do Júri. Tal medida não se encontra prevista em nossa Constituição Federal. ${ }^{81}$

80 SCHREIBER, Simone. Op. cit. pág. 401-404.

81 ARAS, Vladimir. Publicidade Opressiva e renúncia ao Júri. Disponível em <https://vladimiraras.blog/2010/05/19/publicidade-opressiva-e-renuncia-ao-juri/>. Acesso em 25 de maio de 2018. 
$\mathrm{O}$ artigo $5^{\circ}$, inciso XXXVIII, da Constituição reconhece a instituição do júri como um direito e uma garantia fundamental, assegurando como um de seus fundamentos a plenitude de defesa, ocorre que, em casos em que houve verdadeira campanha de mídia, o direito a plenitude de defesa se encontraria devastado, uma vez que o júri já teria seu convencimento formado muito antes do próprio julgamento.

Essa medida seria retirada de uma prática comum nos Estados norteamericanos, nos quais o réu pode renunciar ao julgamento diante do Tribunal do Júri, a isso eles denominam de waiver of jury trial.

Posto isso, além das medidas dispostas, neste trabalho, existem inúmeras outras capazes de serem utilizadas quando houver a colisão de direitos fundamentais tão importantes quanto os estudados durante o presente trabalho.

Aquém dessas medidas capazes de dirimir o conflito entre esses direitos fundamentais é necessária uma ressignificação do processo penal, a fim de que este sirva como um instrumento de garantia contra a opressão e como um instrumento contramajoritário, essencial para a concretização dos direitos fundamentais. ${ }^{82}$

Assim, também, afirmam Juarez Tavares, Geraldo Prado e Ademar Borges em seu artigo "A construção midiática de casos criminais pode ofender direitos fundamentais":

82 CASARA, Rubens. A espetacularização do processo penal. Disponível em < http://www.mpsp.mp.br/portal/page/portal/documentacao_e_divulgacao/doc_biblioteca/bibli_servi cos_produtos/bibli_boletim/bibli_bol_2006/122.12.PDF >. Acesso em 25 de maio de 2018. 
(...) não há dúvida de que, se há uma seara em que a jurisdição constitucional deve renunciar ao propósito de alinhamento com a expectativa social difusa, essa seara certamente é o Direito Penal. Nos casos criminais, deve prevalecer a maior distância possível do clamor público, a fim de garantir que a jurisdição seja prestada com imparcialidade e apego superlativo à estrita legalidade. Aqui cabe o STF reafirmar sua condição de instância contramajoritária de proteção aos direitos fundamentais, garantindo o respeito aos direitos fundamentais do acusado em detrimento das expectativas sociais de punição a qualquer custo e das campanhas midiáticas que podem distorcer a compreensão juridicamente adequada das acusações criminais. ${ }^{83}$

Portanto, é necessário um verdadeiro realinhamento da justiça criminal por seus aplicadores, retomando sua função primeira e reiterando a genuína noção de um Estado Democrático de Direito que se firma não só na realização das vontades do interesse coletivo como, também, na proteção dos direitos e garantias fundamentais.

83 TAVARES, Juarez; PRADO, Geraldo; BORGES, Ademar. A construção midiática de casos criminais pode ofender direitos fundamentais. Disponível em < https://www.conjur.com.br/dl/artigo-midia-crime.pdf >. Acesso em 25 de maio de 2018. 


\section{Conclusão}

Com o trabalho apresentado buscou-se demonstrar que os meios de comunicação de massa ao desempenharem a função de informar a população como forma de fiscalizar os atos de seus representantes nem sempre o fazem de forma imparcial e compromissada com a verdade.

Não se está aqui querendo retirar da imprensa seu estimado valor para efetivação da Democracia representativa pois, de fato, é ela quem realiza de forma mais plena os direitos constitucionais da liberdade de expressão e, principalmente, de informação. Entretanto, há que se reequilibrar a balança quando a sua atuação interfere em outros princípios igualmente constitucionais.

O crime é um acontecimento público e que, inevitavelmente, haverá o interesse da coletividade em acompanhar o seu desenrolar. Sendo assim, como foi visto neste estudo, as notícias concernentes ao fato criminoso, ainda que duras ou críticas, não podem ser censuradas.

Ocorre que, como foi demonstrado, por inúmeras vezes, além das violações aos direitos da personalidade, a imprensa deflagrou verdadeiras campanhas de mídia pela condenação do réu, prejudicando, invariavelmente, o direito deste em ser considerado presumidamente inocente e de ser submetido a um julgamento criminal justo.

A mídia, assim, assume o papel de verdadeiro órgão de persecução penal a fim de promover o combate à impunidade. Pressiona os verdadeiros órgãos responsáveis por apurar e julgar os crimes a atender o clamor social de punição a qualquer custo nem que, para isso, seja necessário relativizar as garantias constitucionais. 
Dessa forma, ao ingressar nas pautas midiáticas, o réu investigado torna-se um réu, automaticamente, condenado e não há nenhuma chance de se obter um resultado diferente quando do seu julgamento criminal. O juízo de culpabilidade é formado bem antes, por meio das inúmeras notícias sensacionalistas veiculadas pela mídia e não há nada e nem direito algum que possa mudá-lo.

Infelizmente, vemos que tal prática é corrente nos dias atuais. A cada novo dia podemos observar como o crime virou a principal pauta dos meios de comunicação e como a mídia ao veicular suas notícias exerce sua publicidade opressiva.

As garantias individuais do acusado constitucionalmente estabelecidas e um sistema punitivo orientado pelo princípio da presunção de inocência acabam ficando em um segundo plano dentro de uma sociedade que clama pelo recrudescimento penal como a solução para todos os conflitos.

É necessário, portanto, e buscou-se com o presente estudo, desmistificar a ideia de que ao estabelecermos limites a atuação dessa mídia opressiva e, portanto, a liberdade de expressão e informação, com o intuito de garantir outros direitos de igual relevância constitucional, estaríamos censurando a instituição capaz de efetivar a democracia representativa no país. 
Foram traçadas, dessa forma, medidas compatíveis com a Constituição Federal que poderiam ser adotadas com o intuito de solucionar a colisão apresentada sem implicar em supressões à liberdade de expressão e informação e, em contrapartida, permitindo ao acusado o direito de ser submetido a um julgamento criminal justo.

Após trinta anos da Constituição Federal de 1988 - a "Constituição Cidadã" - o conflito entre a liberdade de expressão e informação e o direito a um julgamento criminal justo ainda é uma realidade no Brasil. A publicidade opressiva, apesar de um fato, deve ser combatida pelo Poder Judiciário, pois ao se garantir o direito individual de um, também, se estará garantindo o direito de todos.

Por fim, termino este trabalho com uma frase, extraída de uma série documentário chamada "Making a Murderer", que diz: "Você pode mesmo jamais cometer um crime, mas nada impede que a polícia te acuse de ter cometido um crime. "Portanto, evidencia-se a necessidade de se garantir a todos que são acusados de um crime um julgamento criminal justo baseado, principalmente, no princípio da presunção de inocência, já que, hoje, pode até ser o outro que está sentado no "banco dos réus", mas amanhã, este, poderá ser você. 


\section{Bibliografia}

ANDRADE, Fábio Martins de. Mídia e Poder Judiciário: A influência dos órgãos de mídia no Processo Penal Brasileiro. Rio de Janeiro: Lumen Juris, 2007, 447 p.

ARAS, Vladimir. Publicidade Opressiva e renúncia ao Júri. Disponível em $<$ https://vladimiraras.blog/2010/05/19/publicidade-opressiva-e-renuncia-aojuri/>. Acesso em 25 de maio de 2018.

ÁVILA, Humberto. Princípios e regras e a segurança jurídica. Revista de Direito do Estado, ${ }^{\circ} 1$. Rio de Janeiro: Renovar, 2006.

ÁVILA, Humberto. Teoria dos princípios: Da definição à aplicação dos princípios jurídicos. 12ª ed. ampl. São Paulo: Malheiros, 2003, 206 p.

BARCELlOS, Ana Paula de. Ponderação, racionalidade e atividade jurisdicional. Rio de Janeiro: Renovar, 2005.

BARROSO, Luís Roberto. Curso de direito constitucional contemporâneo: os conceitos fundamentais e a construção do novo modelo/Luís Roberto Barroso. - 4 ed. - São Paulo: Saraiva, 2013. 511p.

BATISTA, Nilo. A Corte Europeia já pune "publicidade opressiva" como a usada contra Lula. Disponível em < https://www.viomundo.com.br/denuncias/nilo-batista-corte-europeia-ja-punepublicidade-opressiva-como-a-usada-contra-lula.html >. Acesso em 10 de maio de 2018.

BATISTA, Nilo. Mídia e sistema penal no capitalismo tardio. Disponível em <http://www.bocc.ubi.pt/pag/batista-nilo-midia-sistema-penal.pdf> Acesso em 19 de abril

CASARA, Rubens. A espetacularização do processo penal. Disponível em < http://www.mpsp.mp.br/portal/page/portal/documentacao_e_divulgacao/doc_b iblioteca/bibli_servicos_produtos/bibli_boletim/bibli_bol_2006/122.12.PDF >. Acesso em 18 de abril de 2018. 
DICIONÁRIO, online. Significado de Informação. Disponível em < https://www.dicio.com.br/informacao/ > . Acesso em 30 de abril de 2018.

FERNANDES, Marcelo. A nova lei sobre direito de resposta e a liberdade de imprensa. Disponível em r http://www.migalhas.com.br/dePeso/16,MI239139,51045-

A+nova+lei+sobre+direito+de+resposta+e+a+liberdade+de+imprensa >. Acesso em 08 de maio de 2018.

FERRARI, Rafael. O princípio da presunção de inocência como garantia processual penal. Disponível em < http://www.ambitojuridico.com.br/site/?n_link=revista_artigos_leitura\&artigo_id=11829 >. Acesso em 13 de maio de 2018.

FILHO, Ciro. Dicionário de comunicação. Disponível em < https://books.google.com.br/books?id=pf-

5DAAAQBAJ\&pg=PT32\&dq=agenda+setting+dicionario\&hl=ptBR\&sa $=X \& v e d=0 a h U K E w j H 9 d v 1 k K n b A h W F f p A K H d k x C I s Q 6 A E I K D A A \#$ $\mathrm{v}=$ onepage $\& \mathrm{q}=$ agenda $\% 20$ setting $\% 20$ dicionario $\& \mathrm{f}=$ false $>$ Acesso em $28 \mathrm{de}$ maio de 2018.

FILHO, João. Teoria dos direitos fundamentais. Disponível em < http://www.stf.jus.br/repositorio/cms/portaltvjustica/portaltvjusticanoticia/anex o/joao_trindadade_teoria_geral_dos_direitos_fundamentais.pdf $>$. Acesso em 27 de abril de 2018.

FREITAS, Paulo Henrique. Julgamentos midiáticos: O princípio da publicidade e o direito a um julgamento justo (fair trial). Disponível em < https://jus.com.br/artigos/58643/julgamentos-midiaticos-o-principio-dapublicidade-e-o-direito-a-um-julgamento-justo-fair-trial/4 >. Acesso em 24 de maio de 2018.

GOMES, Marcus Alan de Melo. Crítica à cobertura midiática da operação Lava-jato. Disponível em < http://www.mpsp.mp.br/portal/page/portal/documentacao_e_divulgacao/doc_b iblioteca/bibli_servicos_produtos/bibli_boletim/bibli_bol_2006/122.09.PDF >. Acesso em 18 de abril de 2018.

GOMES, Marcus Alan de Melo. Mídia e sistema penal: as distorções da criminalização nos meios de comunicação. $1^{a}$ ed. - Rio de Janeiro: Revan, 2015. 157 p. 
KEHDI, André. Editorial: Mídia, imagem e poder na democracia. Disponível em <https://www.ibccrim.org.br/boletim_artigo/4062EDITORIAL-Midia-imagem-e-poder-na-democracia >. Acesso em 18 de abril de 2018.

LOPES JR., Aury. Direito Processual Penal. - 12. ed. - São Paulo: Saraiva, 2015. 1148 p.

MENUCI, Julia Monfardini; FERREIRA, Laura Pinto; MENEGAT, Isabela Costa. A influência da mídia no processo penal. Disponível em < http://egov.ufsc.br/portal/sites/default/files/28225-61308-1-pb.pdf> Acesso em. 02 de abril de 2018.

NAPOLITANO, Carlo. Liberdade de imprensa no Supremo Tribunal Federal: Análise comparativa com a Suprema Corte dos Estados Unidos. Disponível em < http://www.scielo.br/pdf/interc/v38n1/1809-5844-interc-3801-0019.pdf > . Acesso em 10 de maio de 2018.

NUCCI, Guilherme de Souza. Código de processo penal comentado. 10. ed. rev., atual. E ampl. São Paulo: Editora Revista dos Tribunais, 2011. 1310 p.

PERIPOLLI, Suzana; DIAS, Monia. Colisão de direitos: Liberdade de imprensa e presunção de inocência. Disponível em < http://coral.ufsm.br/congressodireito/anais/2015/2-9.pdf >. Acesso em $02 \mathrm{de}$ maio de 2018.

ROCHA, Rebeca; FERNANDES, Amanda. A vitimização e a condenação prévia no plano midiático. Disponível em < file:///C:/Users/Asus/Downloads/7197-18453-1-PB.pdf > Acesso em 19 de abril de 2018.

SCHREIBER, Simone. A publicidade opressiva de julgamentos criminais. Rio de Janeiro: Renovar, 2008. 413 p.

SILVA, José Afonso. Curso de Direito Constitucional Positivo. $37^{\text {a }}$ edição. $934 \mathrm{p}$.

SOARES, Fábio. Liberdade de comunicação. Proibição de censura e limites. Disponível em < http://www.emerj.tjrj.jus.br/serieaperfeicoamentodemagistrados/paginas/series/ 11/normatividadejuridica_60.pdf>. Acesso em 04 de maio de 2018. 
STF, Rcl. No 18638, Rel. Ministro Luís Roberto Barroso, Brasília, 2 de maio. 2018. Disponível em < https://stf.jusbrasil.com.br/jurisprudencia/574029873/reclamacao-rcl-18638ce-ceara-9998385-2220141000000 > Acesso em 10 de maio de 2018.

STJ, Resp. no 984803, Rel. Ministra Nancy Andrighi. Brasília, 26 de maio. 2009. Disponível em < https://ww2.stj.jus.br/processo/pesquisa/? $\mathrm{src}=1.1 .2 \&$ aplicacao $=$ processos.ea\&tipoPesquisa=tipoPesquisaGenerica\&num _registro=200702099361 >. Acesso em 08 de maio de 2018.

TAVARES, Juarez, PRADO, Geraldo e BORGES, Ademar. A construção midiática de casos criminais pode ofender direitos fundamentais. Disponível em < https://www.conjur.com.br/dl/artigo-midia-crime.pdf >. Acesso em 25 de maio de 2018.

TEIXEIRA, Paulo Victor. "Foi condenado por causa da mídia", dispara exadvogado do goleiro Bruno. Disponível em < http://www.olhardireto.com.br/juridico/noticias/exibir.asp?id=35917\&noticia= foi-condenado-por-causa-da-midia-dispara-ex-advogado-do-goleiro-brunoveja-entrevista-exclusiva- >. Acesso em 15 de maio de 2018.

TJ-RJ, Ap. Cível no 00567632820148190001, Rel. Des. Horácio dos Santos Ribeiro Neto. Rio de Janeiro, 14 de março. 2017. Disponível em < https://tjrj.jusbrasil.com.br/jurisprudencia/442574378/apelacao-apl-

567632820148190001-rio-de-janeiro-capital-22-vara-civel >. Acesso em 08 de maio de 2018.

TJ-RS, Ap. Cível no 70073985319, Rel. Des. Túlio de Oliveira Martins. Porto Alegre, 28 de setembro. 2017. Disponível em < https://tjrs.jusbrasil.com.br/jurisprudencia/507432858/apelacao-civel-ac-70073985319rs/inteiro-teor-507432895? ref=juris-tabs > Acesso em 08 de maio de 2018.

WIKIPEDIA, significado de Trial by media. Disponível em <https://en.wikipedia.org/wiki/Trial_by_media >. Acesso em 23 de maio de 2018. 